\title{
LEVEL II SCOUR ANALYSIS FOR BRIDGE 11 (BELVTH00080011) on TOWN HIGHWAY 8, crossing the NORTH BRANCH LAMOILLE RIVER, BELVIDERE, VERMONT
}

U.S. Geological Survey Open-File Report 98-278

Prepared in cooperation with

VERMONT AGENCY OF TRANSPORTATION and

FEDERAL HIGHWAY ADMINISTRATION

U.S. Department of the Interior

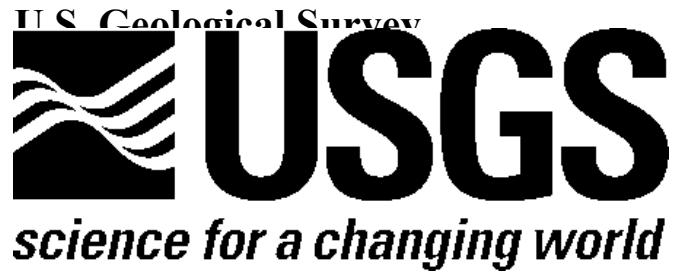




\section{LEVEL II SCOUR ANALYSIS FOR}

BRIDGE 11 (BELVTH00080011) on

TOWN HIGHWAY 8, crossing the NORTH BRANCH LAMOILLE RIVER,

BELVIDERE, VERMONT

By ERICK M. BOEHMLER AND JAMES R. DEGNAN

U.S. Geological Survey

Open-File Report 98-278

Prepared in cooperation with

VERMONT AGENCY OF TRANSPORTATION

and

FEDERAL HIGHWAY ADMINISTRATION 


\title{
U.S. DEPARTMENT OF THE INTERIOR BRUCE BABBITT, Secretary
}

\author{
U.S. GEOLOGICAL SURVEY
}

Thomas J. Casadevall, Acting Director

For additional information write to:

District Chief

U.S. Geological Survey 361 Commerce Way

Pembroke, NH 03275-3718
Copies of this report may be purchased from:

U.S. Geological Survey

Branch of Information Services

Open-File Reports Unit

Box 25286

Denver, CO 80225-0286 


\section{CONTENTS}

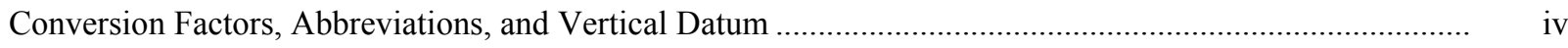

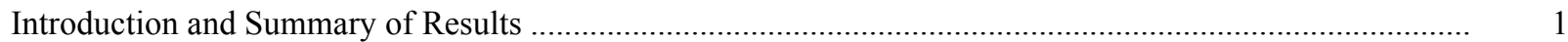

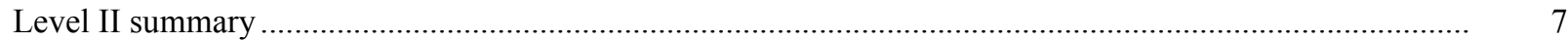

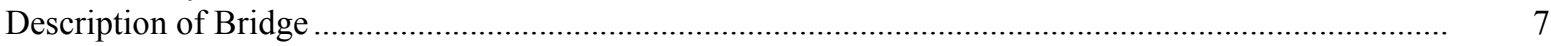

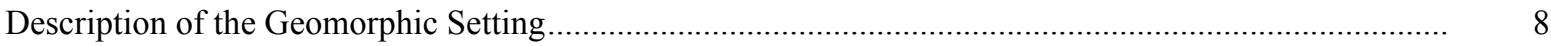

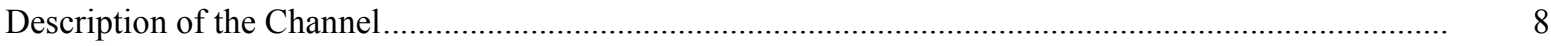

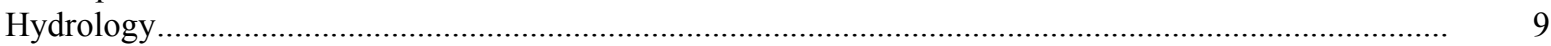

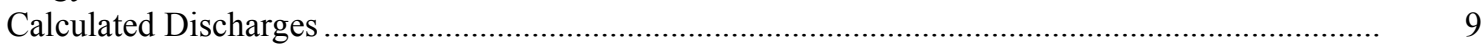

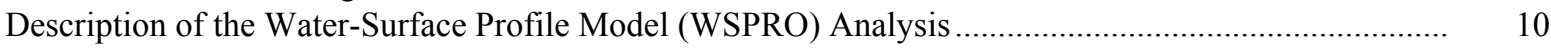

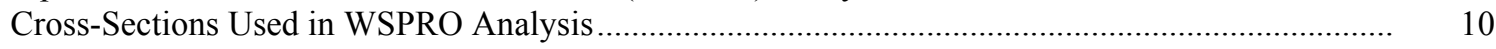

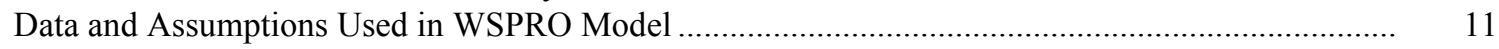

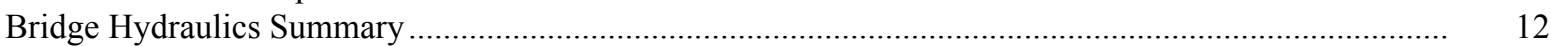

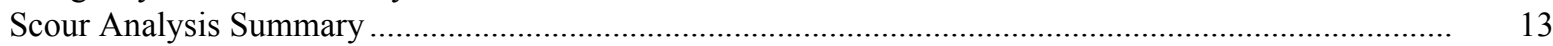

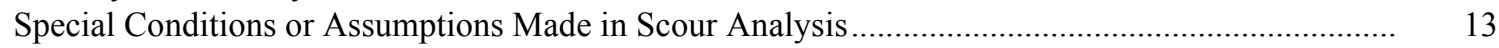

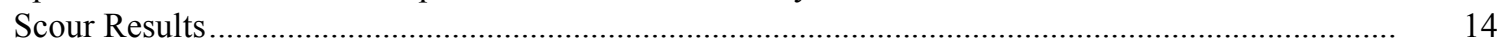

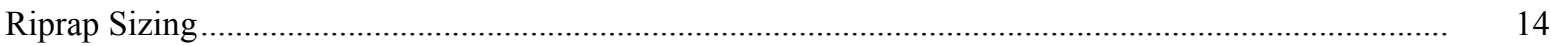

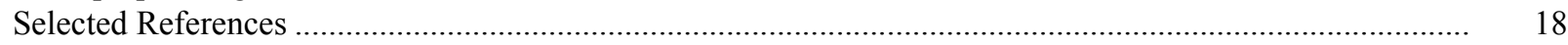

Appendices:

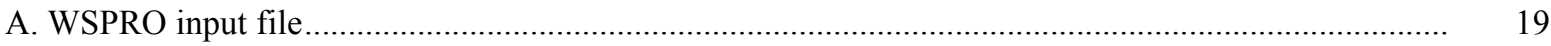

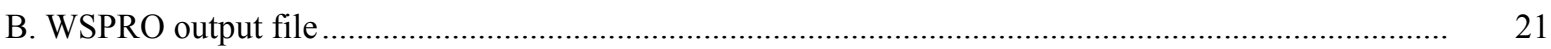

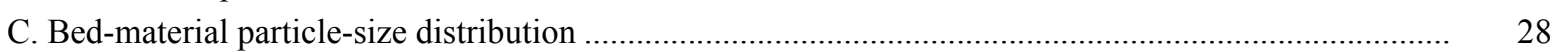

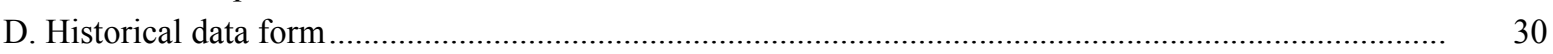

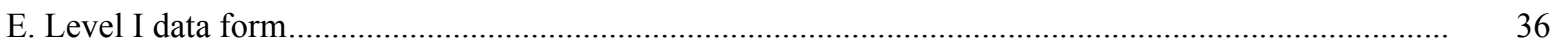

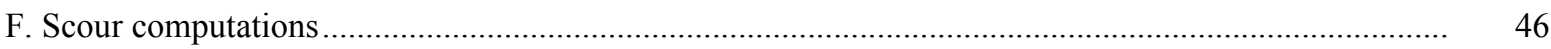

\section{FIGURES}

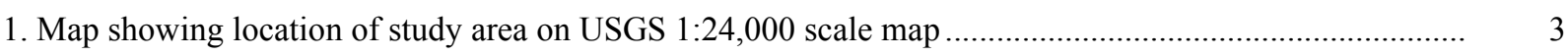

2. Map showing location of study area on Vermont Agency of Transportation town

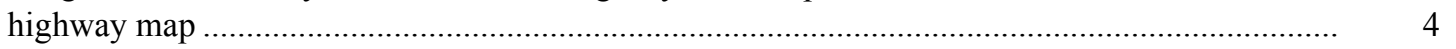

3. Structure BELVTH00080011 viewed from upstream (June 27, 1995) ................................................ 5

4. Downstream channel viewed from structure BELVTH00080011 (June 27, 1995)................................ 5

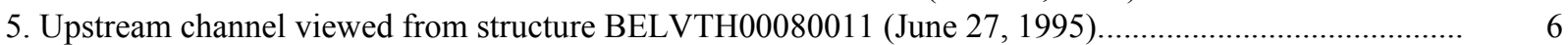

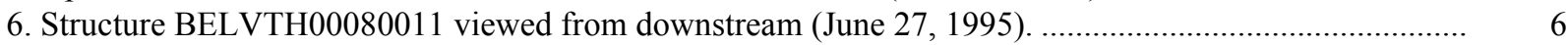

7. Water-surface profiles for the 100- and 500-year discharges at structure

BELVTH00080011 on Town Highway 8, crossing the North Branch Lamoille River,

Belvidere, Vermont.

8. Scour elevations for the 100- and 500-year discharges at structure

BELVTH00080011 on Town Highway 8, crossing the North Branch Lamoille River,

Belvidere, Vermont.

\section{TABLES}

1. Remaining footing/pile depth at abutments for the 100-year discharge at structure

BELVTH00080011 on Town Highway 8, crossing the North Branch Lamoille River,

Belvidere, Vermont.

2. Remaining footing/pile depth at abutments for the 500-year discharge at structure

BELVTH00080011 on Town Highway 8, crossing the North Branch Lamoille River,

Belvidere, Vermont. 


\begin{tabular}{|c|c|c|}
\hline Multiply & By & To obtain \\
\hline \multicolumn{3}{|c|}{ Length } \\
\hline inch (in.) & 25.4 & millimeter $(\mathrm{mm})$ \\
\hline foot $(\mathrm{ft})$ & 0.3048 & meter $(\mathrm{m})$ \\
\hline mile (mi) & 1.609 & kilometer $(\mathrm{km})$ \\
\hline \multicolumn{3}{|c|}{ Slope } \\
\hline foot per mile (ft/mi) & 0.1894 & meter per kilometer $(\mathrm{m} / \mathrm{km})$ \\
\hline \multicolumn{3}{|c|}{ Area } \\
\hline square mile $\left(\mathrm{mi}^{2}\right)$ & 2.590 & square kilometer $\left(\mathrm{km}^{2}\right)$ \\
\hline \multicolumn{3}{|c|}{ Volume } \\
\hline cubic foot $\left(\mathrm{ft}^{3}\right)$ & $\begin{array}{l}0.02832 \\
\text { Velocity and Flow }\end{array}$ & cubic meter $\left(\mathrm{m}^{3}\right)$ \\
\hline foot per second $(\mathrm{ft} / \mathrm{s})$ & 0.3048 & meter per second $(\mathrm{m} / \mathrm{s})$ \\
\hline cubic foot per second $\left(\mathrm{ft}^{3} / \mathrm{s}\right)$ & 0.02832 & cubic meter per second $\left(\mathrm{m}^{3} / \mathrm{s}\right.$ \\
\hline $\begin{array}{l}\text { cubic foot per second per } \\
\text { square mile } \\
{\left[\left(\mathrm{ft}^{3} / \mathrm{s}\right) / \mathrm{mi}^{2}\right]}\end{array}$ & 0.01093 & $\begin{array}{l}\text { cubic meter per } \\
\text { second per square } \\
\text { kilometer }\left[\left(\mathrm{m}^{3} / \mathrm{s}\right) / \mathrm{km}^{2}\right.\end{array}$ \\
\hline
\end{tabular}

\section{OTHER ABBREVIATIONS}

\begin{tabular}{|c|c|c|c|}
\hline $\mathrm{BF}$ & bank full & LWW & left wingwall \\
\hline $\mathrm{cfs}$ & cubic feet per second & Max & maximum \\
\hline $\mathrm{D}_{50}$ & median diameter of bed material & $\mathrm{MC}$ & main channel \\
\hline DS & downstream & RAB & right abutment \\
\hline elev. & elevation & RABUT & face of right abutment \\
\hline $\mathrm{f} / \mathrm{p}$ & flood plain & $\mathrm{RB}$ & right bank \\
\hline $\mathrm{ft}^{2}$ & square feet & $\mathrm{ROB}$ & right overbank \\
\hline $\mathrm{ft} / \mathrm{ft}$ & feet per foot & RWW & right wingwall \\
\hline FEMA & Federal Emergency Management Agency & $\mathrm{TH}$ & town highway \\
\hline FHWA & Federal Highway Administration & UB & under bridge \\
\hline JCT & junction & US & upstream \\
\hline LAB & left abutment & USGS & United States Geological Survey \\
\hline LABUT & face of left abutment & VTAOT & Vermont Agency of Transportation \\
\hline LB & left bank & WSPRO & water-surface profile model \\
\hline LOB & left overbank & $\mathrm{yr}$ & year \\
\hline
\end{tabular}

In this report, the words "right" and "left" refer to directions that would be reported by an observer facing downstream. Sea level: In this report, "sea level” refers to the National Geodetic Vertical Datum of 1929-- a geodetic datum derived from a general adjustment of the first-order level nets of the United States and Canada, formerly called Sea Level Datum of 1929.

In the appendices, the above abbreviations may be combined. For example, USLB would represent upstream left bank. 


\title{
LEVEL II SCOUR ANALYSIS FOR BRIDGE 11 (BELVTH00080011) ON TOWN HIGHWAY 8, CROSSING THE NORTH BRANCH LAMOILLE RIVER, BELVIDERE, VERMONT
}

\author{
By Erick M. Boehmler and James R. Degnan
}

\section{INTRODUCTION AND SUMMARY OF RESULTS}

This report provides the results of a detailed Level II analysis of scour potential at structure BELVTH00080011 on Town Highway 8 crossing the North Branch Lamoille River, Belvidere, Vermont (figures 1-8). A Level II study is a basic engineering analysis of the site, including a quantitative analysis of stream stability and scour (FHWA, 1993). Results of a Level I scour investigation also are included in appendix E of this report. A Level I investigation provides a qualitative geomorphic characterization of the study site. Information on the bridge, gleaned from Vermont Agency of Transportation (VTAOT) files, was compiled prior to conducting Level I and Level II analyses and is found in appendix D.

The site is in the Green Mountain section of the New England physiographic province in north-central Vermont. The $23.4-\mathrm{mi}^{2}$ drainage area is in a predominantly rural and forested basin. In the vicinity of the study site, the surface cover consists of short grass, a few houses, and gravel driveways except for the right overbank downstream, which is forest.

In the study area, the North Branch Lamoille River has an incised, sinuous channel with a slope of approximately $0.04 \mathrm{ft} / \mathrm{ft}$, an average channel top width of $72 \mathrm{feet}$ and an average bank height of $9 \mathrm{ft}$. The predominant channel bed materials are cobbles and boulders with a median grain size $\left(\mathrm{D}_{50}\right)$ of $172 \mathrm{~mm}(0.566 \mathrm{ft})$. The geomorphic assessment at the time of the Level I and Level II site visit on June 27, 1995, indicated that the reach was stable.

The Town Highway 8 crossing of the North Branch Lamoille River is a 40-ft-long, one-lane bridge consisting of one 37-foot steel-beam span (Vermont Agency of Transportation, written communication, March 7, 1995). The bridge is supported by vertical, concrete abutments with wingwalls on the left abutment. The channel is skewed approximately 35 degrees to the opening while the opening-skew-to-roadway is zero degrees.

The scour protection measures at the site were type- 2 stone fill (less than 36 inches diameter) along the right abutment wall and type- 3 stone fill along the left abutment, the upstream and downstream left wingwalls and the upstream right roadway embankment. Additional details describing conditions at the site are included in the Level II Summary and appendices D and E. 
Scour depths and recommended rock rip-rap sizes were computed using the general guidelines described in Hydraulic Engineering Circular 18 (Richardson and others, 1995). Total scour at a highway crossing is comprised of three components: 1) long-term streambed degradation; 2) contraction scour (due to accelerated flow caused by a reduction in flow area at a bridge) and; 3) local scour (caused by accelerated flow around piers and abutments). Total scour is the sum of the three components. Equations are available to compute depths for contraction and local scour and a summary of the results of these computations follows.

Contraction scour for all modelled flows ranged from 0.6 to 0.9 feet. The worst-case contraction scour occurred at the 500-year discharge. Abutment scour ranged from 6.9 to 22.2 feet. The worst-case abutment scour occurred at the 500 -year discharge. Additional information on scour depths and depths to armoring are included in the section titled "Scour Results". Scoured-streambed elevations, based on the calculated scour depths, are presented in tables 1 and 2. A cross-section of the scour computed at the bridge is presented in figure 8. Scour depths were calculated assuming an infinite depth of erosive material and a homogeneous particle-size distribution.

It is generally accepted that the Froehlich equation (abutment scour) gives "excessively conservative estimates of scour depths" (Richardson and others, 1995, p. 47). Usually, computed scour depths are evaluated in combination with other information including (but not limited to) historical performance during flood events, the geomorphic stability assessment, existing scour protection measures, and the results of the hydraulic analyses. Therefore, scour depths adopted by VTAOT may differ from the computed values documented herein. 


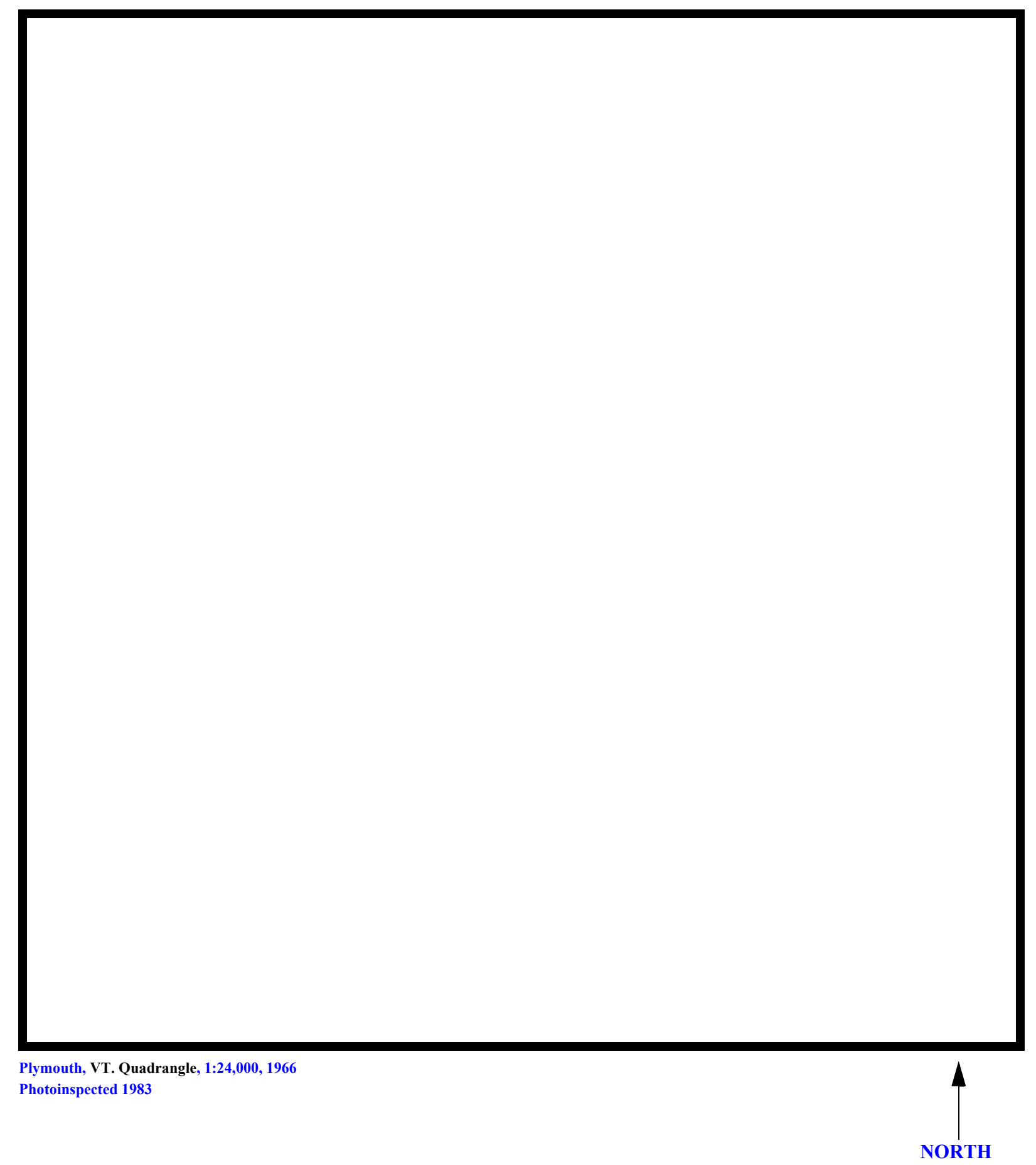

Figure 1. Location of study area on USGS 1:24,000 scale map. 
Figure 2. Location of study area on Vermont Agency of Transportation town highway map. 

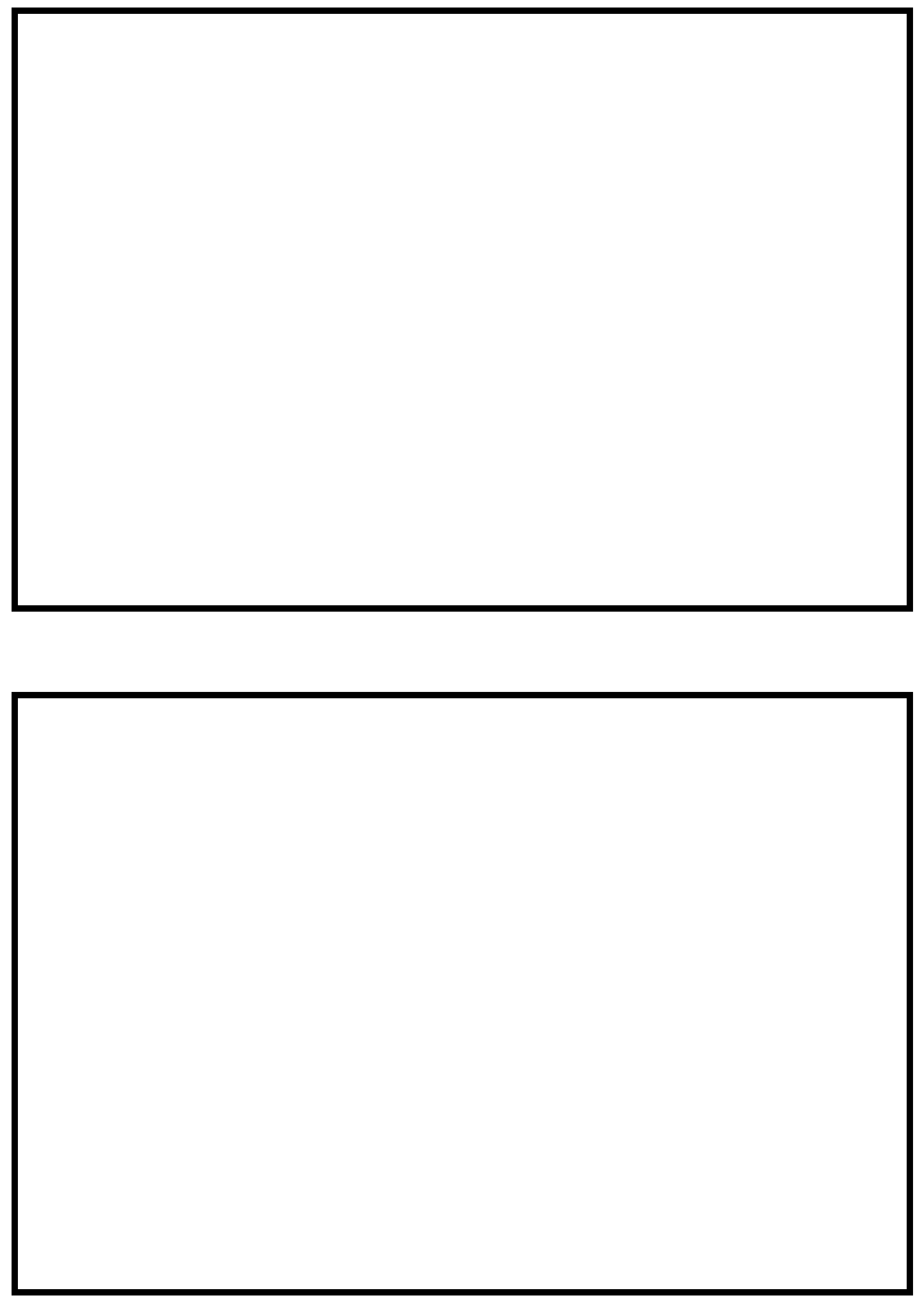

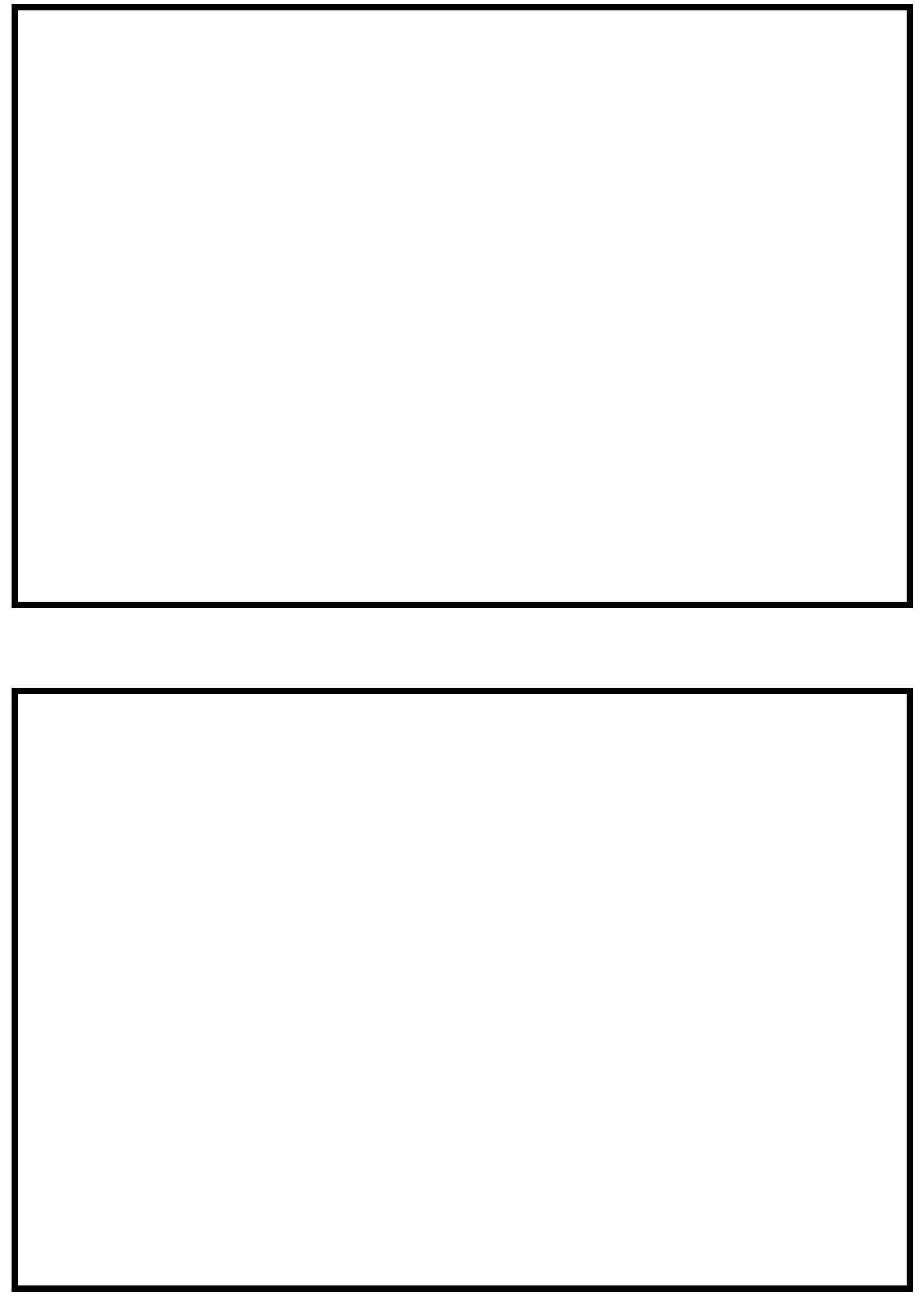


\section{LEVEL II SUMMARY}

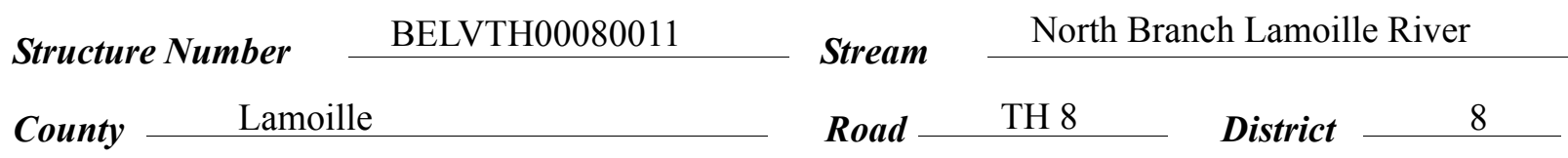

\section{Description of Bridge}

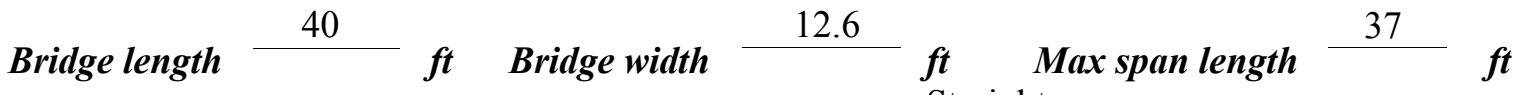
Alignment of bridge to road (on curve or straight) Vertical, concrete Abutment type

Stone fill on abutment?

$$
\text { Yes }
$$

\section{Embankment type} Straight

nananintion af ats... fill Type-3 on the right roadway embankment upstream, the left abutment Sloping nearly vertical and its wingwalls.Type- 2 along the right abutment.

\section{Abutments and wingwalls are "laid-up" stone walls.}

The stone has a concrete facing on the left abutment and its wingwalls.

$$
\text { Yes }
$$

Is bridge skewed to flood flow according to Yes ' survey?

Angle

There is a mild channel bend in the upstream reach. High flows primarily impact the right roadway embankment and the left abutment.

\begin{tabular}{|c|c|c|c|}
\hline & $\begin{array}{c}\text { Date of insmortion } \\
6 / 27 / 95 \\
\end{array}$ & $\begin{array}{l}\text { Percent of alommal } \\
\text { blocked nortzontatly }\end{array}$ & $\begin{array}{l}\text { Percent of } 0 \\
\text { blocked verticatty }\end{array}$ \\
\hline & $6 / 27 / 95$ & 0 & 0 \\
\hline
\end{tabular}

Debris accumulation on bridge at time of Level I or Level II site visit:

Level II Low. Although there is significant vegetation cover on the banks, the channel is stable.

Potential for debris

None evident on 6/27/95.

Dosriho anv, fonturos noar ar at tho hridoo that mav affort flow, (includo ahsorvation dato) 


\section{Description of the Geomorphic Setting}

General topography The channel is located in a moderate relief valley setting with narrow, irregular overbanks and steep valley walls on both sides.

Geomorphic conditions at bridge site: downstream (DS), upstream (US)

Date of inspection $\quad 6 / 27 / 95$

DS left: $\quad$ Steep channel bank to a narrow overbank.

DS right: $\quad$ Steep channel bank and the valley wall.

US left: $\quad$ Steep channel bank and a narrow overbank.

US right: Moderately sloping channel bank and valley wall.

\section{Description of the Channel}

\begin{tabular}{|c|c|c|c|}
\hline \multirow[b]{2}{*}{ Average top width } & & \multirow[b]{2}{*}{ Average depth } & \multirow{2}{*}{$\frac{9}{\text { Cobbles / Boulders }}$} \\
\hline & Cobbles / Boulders & & \\
\hline Predominant bed material & & Bank material & Perennial but flashy \\
\hline
\end{tabular}

$6 / 27 / 95$

Vegetative ${ }^{1}{ }^{1}$ Trees, shrubs, $\cdots$ and brush with short grass on the overbank.

DS left: $\quad$ Trees

DS right: $\quad$ Trees with short grass on the overbank.

US left: $\quad$ Trees.

US right: $\quad$ Yes

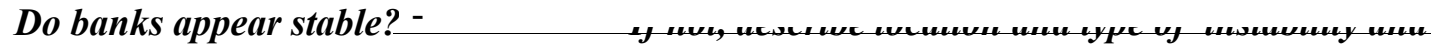

date of observatton.

The assessment of

$6 / 27 / 95$ noted up to $50 \%$ of the channel width immediately downstream of the bridge was Describe any obstructions in channel and date of observation.

occupied by very large boulders on the left side. 


\title{
Hydrology
}

Drainage area $\stackrel{23.4}{\mathrm{mi}^{2}}$

Percentage of drainage area in physiographic provinces: (approximate)

Physiographic province/section

New England/Green Mountain
Percent of drainage area 100

\begin{abstract}
Is drainage area considered rural or urban? Rural Describe any significant urbanization:
\end{abstract}

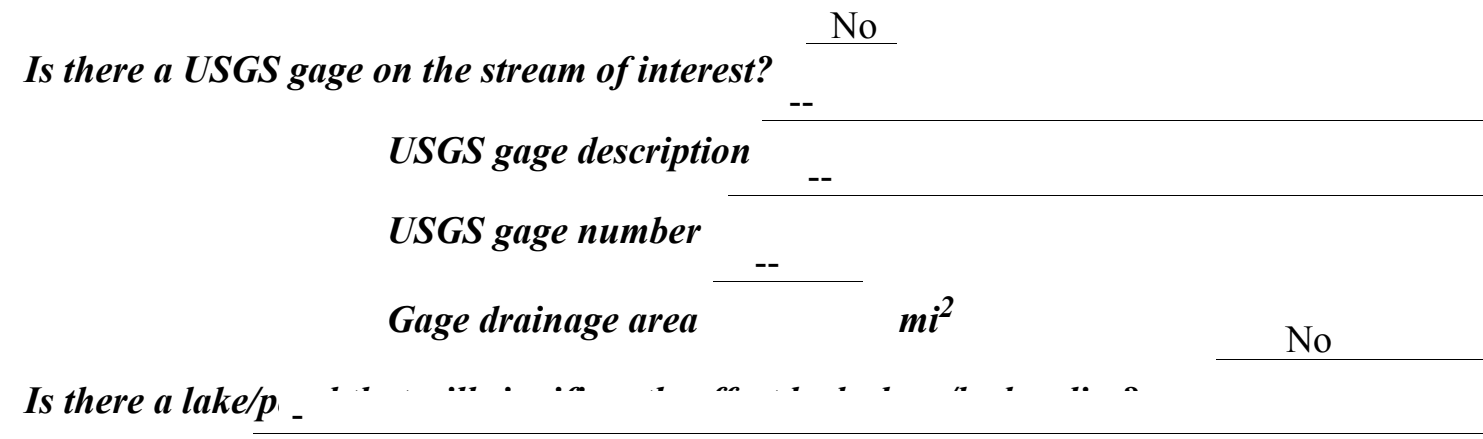

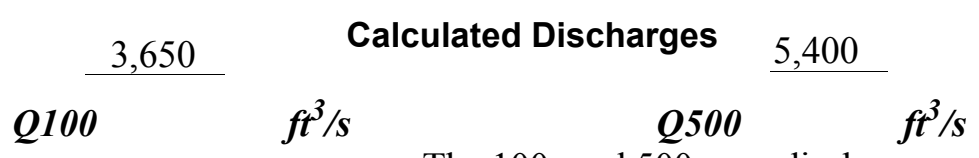

The 100- and 500-year discharges are based on the

flood frequency curve computed by use of the New England Hills and Lowlands empirical relationship (Potter, 1957). The resulting curve was within a range of flood frequency curves computed by use of several other empirical relationships. (Benson, 1962; FHWA, 1983; Johnson and Tasker, 1974; Talbot, 1887). 


\section{Description of the Water-Surface Profile Model (WSPRO) Analysis}

Datum for WSPRO analysis (USGS survey, sea level, VTAOT plans)

USGS survey

Datum tie between USGS survey and VTAOT plans

None

Description of reference marks used to determine USGS datum. $\quad$ RM1 is an orange

painted nail hole in the top of the upstream end of the right abutment concrete cap (elev. 499.71

feet, arbitrary survey datum). RM2 is an orange painted nail hole in the top of the downstream

end of the left abutment concrete cap (elev. 499.64 feet, arbitrary survey datum).

\section{Cross-Sections Used in WSPRO Analysis}

\begin{tabular}{ccll}
\hline${ }^{1}$ Cross-section & $\begin{array}{c}\text { Section } \\
\text { Reference } \\
\text { Distance } \\
\text { (SRD) } \text { in feet }\end{array}$ & $\begin{array}{c}{ }^{2} \text { Cross-section } \\
\text { development }\end{array}$ & \multicolumn{1}{c}{ Comments } \\
\hline EXIT1 & -29 & 1 & Exit section \\
FULLV & 0 & 2 & $\begin{array}{l}\text { Downstream Full-valley } \\
\text { section (Templated from } \\
\text { EXIT1) }\end{array}$ \\
BRIDG & 0 & 1 & $\begin{array}{l}\text { Bridge section } \\
\text { Road Grade section }\end{array}$ \\
RDWAY & 8 & 1 & $\begin{array}{l}\text { Modelled Approach } \\
\text { section (Templated from } \\
\text { APTEM) }\end{array}$ \\
APTEM & 49 & 2 & $\begin{array}{l}\text { Approach section as } \\
\text { surveyed (Used as a } \\
\text { template) }\end{array}$ \\
\hline
\end{tabular}

${ }^{1}$ For location of cross-sections see plan-view sketch included with Level I field form, Appendix E.

For more detail on how cross-sections were developed see WSPRO input file. 


\section{Data and Assumptions Used in WSPRO Model}

Hydraulic analyses of the reach were done by use of the Federal Highway Administration's WSPRO step-backwater computer program (Shearman and others, 1986, and Shearman, 1990). The analyses reported herein reflect conditions existing at the site at the time of the study. Furthermore, in the development of the model it was necessary to assume no accumulation of debris or ice at the site. Results of the hydraulic model are presented in the Bridge Hydraulic Summary, appendix B, and figure 7.

Channel roughness factors (Manning's " $n$ ") used in the hydraulic model were estimated using field inspections at each cross section following the general guidelines described by Arcement and Schneider (1989). Final adjustments to the values were made during the modelling of the reach. Channel " $n$ " values for the reach ranged from 0.055 to 0.065 , and overbank " $\mathrm{n}$ " values ranged from 0.035 to 0.055 .

Normal depth at the exit section (EXIT1) was assumed as the starting water surface. This depth was computed by use of the slope-conveyance method outlined in the user's manual for WSPRO (Shearman, 1990). The slope used was $0.0357 \mathrm{ft} / \mathrm{ft}$, which was estimated from the topographic map (U.S. Geological Survey, 1986).

The surveyed approach section (APTEM) was moved along the approach channel slope $(0.0536 \mathrm{ft} / \mathrm{ft})$ to establish the modelled approach section (APPRO), one bridge length upstream of the upstream face as recommended by Shearman and others (1986). This location also provides a consistent method for determining scour variables.

For the 100-year and incipient-overtopping discharge, WSPRO assumes critical depth at the bridge section. Supercritical models were developed for these discharges. After analyzing both the supercritical and subcritical profiles for each discharge, it can be determined that the water surface profile does pass through critical depth within the bridge opening. Thus, the assumptions of critical depth at the bridge are satisfactory solutions. 


\section{Bridge Hydraulics Summary}

$\begin{array}{llll}\text { Average bridge embankment elevation } & 500.3 & f t \\ \text { Average low steel elevation } & 498.1 & \boldsymbol{f t}\end{array}$

100-year discharge $\quad 3,650 \quad \mathrm{ft}^{3} / \mathrm{s}$

Water-surface elevation in bridge opening $\quad 493.7 \quad f t$

Road overtopping? ___ No Discharge over road ___-- $\mathrm{ft}^{3} / \mathrm{s}$

Area of flow in bridge opening $\quad 234 \quad \mathrm{ft}^{2}$

Average velocity in bridge opening $15.6 \mathrm{ft} / \mathrm{s}$

$\begin{array}{llll}\text { Maximum WSPRO tube velocity at bridge } & 20.8 \mathrm{ft} / \mathrm{s}\end{array}$

Water-surface elevation at Approach section with bridge 498.4

Water-surface elevation at Approach section without bridge $\quad 493.8$

Amount of backwater caused by bridge $\quad 4.6 \quad$ it

500-year discharge $\quad 5,400 \quad \mathrm{ft}^{3} / \mathrm{s}$

Water-surface elevation in bridge opening

$498.1 \mathrm{ft}$

Road overtopping? ___ Yes Discharge over road __ $1050 \quad \mathrm{ft}^{3} / \mathrm{s}$

Area of flow in bridge opening $\quad 373 \quad \mathrm{ft}^{2}$

Average velocity in bridge opening $11.7 \mathrm{ft} / \mathrm{s}$

Maximum WSPRO tube velocity at bridge 16.3 _s

Water-surface elevation at Approach section with bridge 501.7

Water-surface elevation at Approach section without bridge $\quad 495.6$

Amount of backwater caused by bridge 6.1 , $t$

Incipient overtopping discharge $\quad 3,670 \quad \mathrm{ft}^{3} / \mathrm{s}$

Water-surface elevation in bridge opening $493.7 \quad t$

Area of flow in bridge opening $\quad 235 \quad \mathrm{ft}^{2}$

Average velocity in bridge opening $\quad 15.6 \quad \mathrm{ft} / \mathrm{s}$

Maximum WSPRO tube velocity at bridge $\quad 20.7 \mathrm{ft} / \mathrm{s}$

Water-surface elevation at Approach section with bridge

Water-surface elevation at Approach section without bridge

498.4

Amount of backwater caused by bridge $\quad 4.6$, 


\section{Scour Analysis Summary}

\section{Special Conditions or Assumptions Made in Scour Analysis}

Scour depths were computed using the general guidelines described in Hydraulic Engineering Circular 18 (Richardson and others, 1995). Scour depths were calculated assuming an infinite depth of erosive material and a homogeneous particle-size distribution. The results of the scour analysis are presented in tables 1 and 2 and a graph of the scour depths is presented in figure 8 .

Contraction scour for the 100-year and incipient overtopping discharges were computed by use of the Laursen clear-water contraction scour equation (Richardson and others, 1995, p. 32, equation 20). At this site, the 500-year discharge resulted in unsubmerged orifice flow. Contraction scour at bridges with orifice flow is best estimated by use of the Chang pressure-flow scour equation (oral communication, J. Sterling Jones, October 4,1996$)$. Thus, for the 500 -year discharge contraction scour was computed by use of the Chang equation (Richardson and others, 1995, p. 145-146). Results of this analysis are presented in figure 8 and tables 1 and 2. The computed streambed armoring depths suggest that armoring will not limit the depth of contraction scour.

Additional estimates of contraction scour for the 500-year event also were computed by use of Laursen's clear-water scour equation and the Umbrell pressure-flow equation (Richardson and others, 1995, p. 144) and are presented in appendix F. Furthermore, contraction scour was computed by substituting alternative estimates for the depth of flow in the bridge at the downstream face in the scour equations. Contraction scour results with respect to these substitutions also are provided in appendix F.

Abutment scour for the right abutment was computed by use of the Froehlich equation (Richardson and others, 1995, p. 48, equation 28). Variables for the Froehlich equation include the Froude number of the flow approaching the embankments, the length of the embankment blocking flow, and the depth of flow approaching the embankment less any roadway overtopping.

Scour at the left abutment was computed by use of the HIRE equation (Richardson and others, 1995, p. 49, equation 29) because the HIRE equation is recommended when the length to depth ratio of the embankment blocking flow exceeds 25 . The variables used by the HIRE abutment-scour equation are defined the same as those defined for the Froehlich abutment-scour equation. 


\section{Scour Results}

\section{0-yr discharge 500-yr discharge}

Contraction scour:

(Scour depths in feet)

Main channel

Live-bed scour

Clear-water scour

Depth to armoring

Left overbank

Right overbank

Local scour:

Abutment scour

Left abutment

6.9

13.8

7.1

$20.7-$

$22.2-$

20.7-

Right abutment

Pier scour

Pier 1

Pier 2

Pier 3

\section{Abutments:}

Left abutment

Right abutment

Piers:

Pier 1

Pier 2

overtopping discharge 


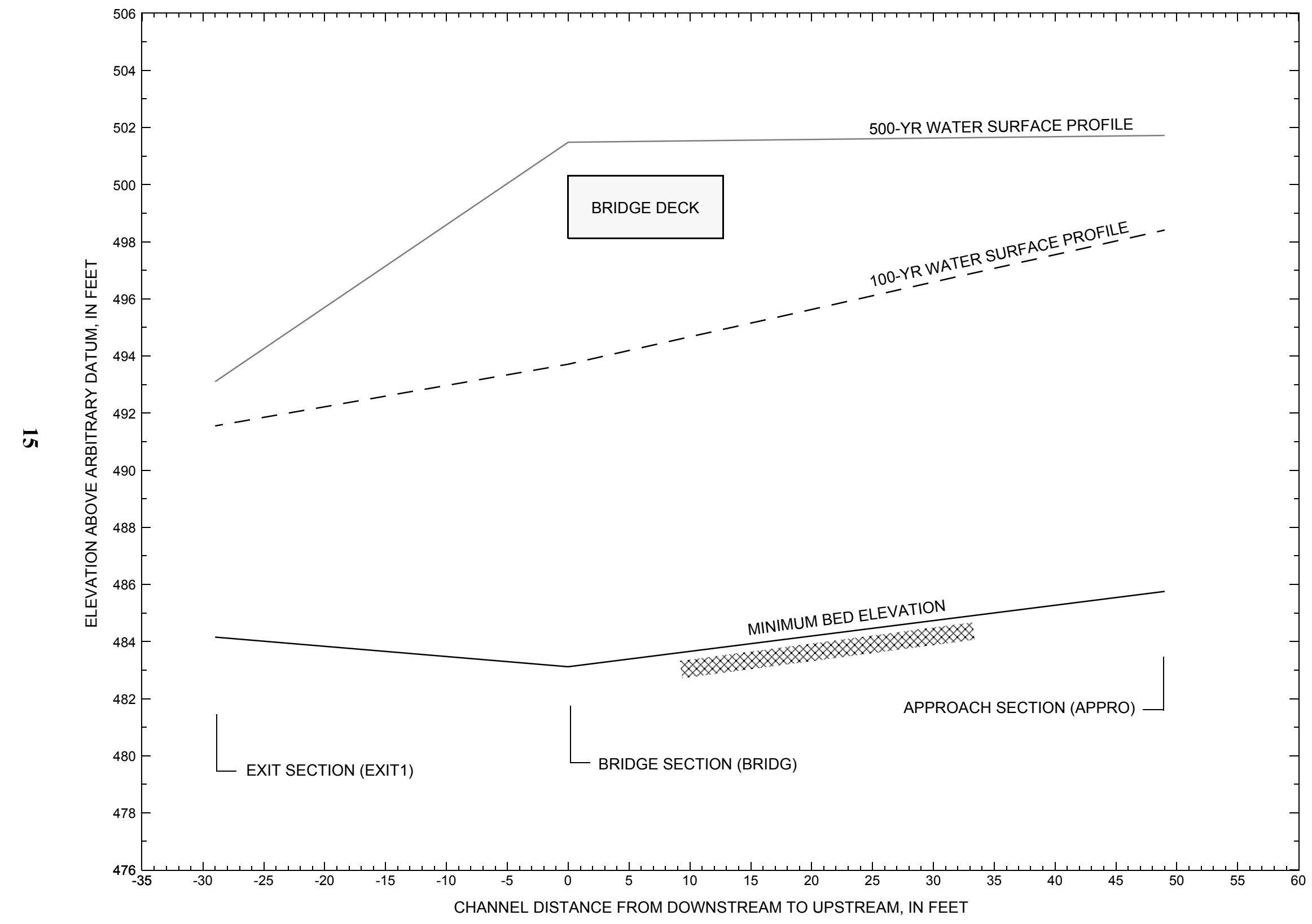

Figure 7. Water-surface profiles for the 100- and 500-year discharges at structure BELVTH00080011 on Town Highway 8, crossing the North Branch Lamoille River, Belvidere, Vermont. 


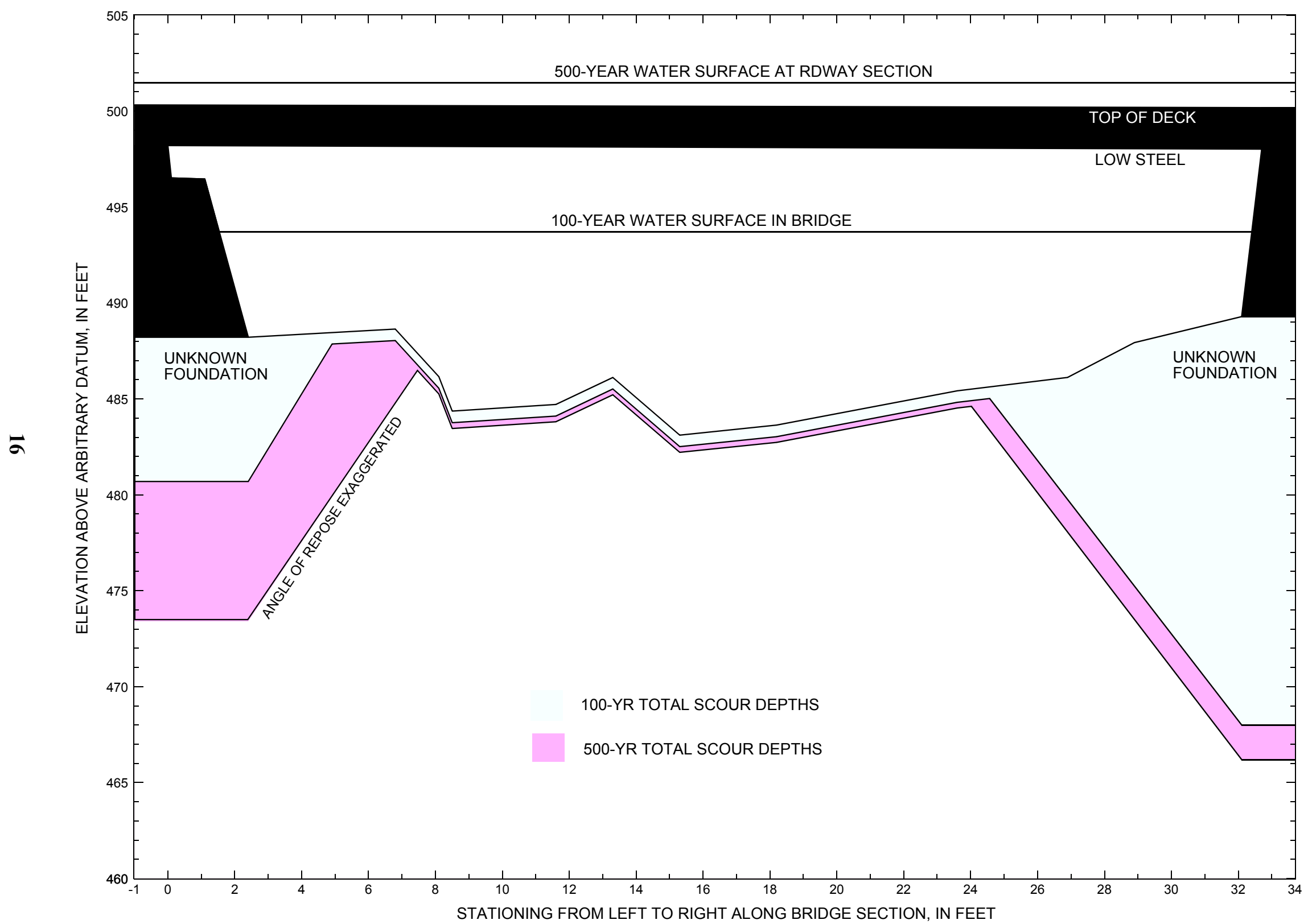

Figure 8. Scour elevations for the 100- and 500-year discharges at structure BELVTH00080011 on Town Highway 8, crossing the North Branch Lamoille River, Belvidere, Vermont. 
Table 1. Remaining footing/pile depth at abutments for the 100-year discharge at structure BELVTH00080011 on Town Highway 8, crossing the North Branch Lamoille River, Belvidere, Vermont

[VTAOT, Vermont Agency of Transportation; --,no data]

\begin{tabular}{|c|c|c|c|c|c|c|c|c|c|c|c|}
\hline Description & Station $^{1}$ & $\begin{array}{l}\text { VTAOT } \\
\text { minimum } \\
\text { low-chord } \\
\text { elevation } \\
\text { (feet) }\end{array}$ & $\begin{array}{l}\text { Surveyed } \\
\text { minimum } \\
\text { low-chord } \\
\text { elevation } \\
\quad \text { (feet) }\end{array}$ & $\begin{array}{c}\text { Bottom of } \\
\text { footing } \\
\text { elevation } \\
\text { (feet) }\end{array}$ & $\begin{array}{c}\text { Channel } \\
\text { elevation at } \\
\text { abutment/ } \\
\text { pier }^{2} \\
\text { (feet) }\end{array}$ & $\begin{array}{l}\text { Contraction } \\
\text { scour depth } \\
\text { (feet) }\end{array}$ & $\begin{array}{l}\text { Abutment } \\
\text { scour } \\
\text { depth } \\
\text { (feet) }\end{array}$ & $\begin{array}{l}\text { Pier } \\
\text { scour } \\
\text { depth } \\
\text { (feet) }\end{array}$ & $\begin{array}{l}\text { Depth of } \\
\text { total scour } \\
\text { (feet) }\end{array}$ & $\begin{array}{c}\text { Elevation of } \\
\text { scour }^{2} \\
\text { (feet) }\end{array}$ & $\begin{array}{c}\text { Remaining } \\
\text { footing/pile } \\
\text { depth } \\
\text { (feet) }\end{array}$ \\
\hline \multicolumn{12}{|c|}{100 -year discharge is 3,650 cubic-feet per second } \\
\hline Left abutment & 0.0 & -- & 498.2 & -- & 488.2 & 0.6 & 6.9 & -- & 7.5 & 480.7 & -- \\
\hline Right abutment & 32.7 & -- & 498.0 & -- & 489.3 & 0.6 & 20.7 & -- & 21.3 & 468.0 & -- \\
\hline
\end{tabular}

1.Measured along the face of the most constricting side of the bridge.

2.Arbitrary datum for this study.

Table 2. Remaining footing/pile depth at abutments for the 500-year discharge at structure BELVTH00080011 on Town Highway 8, crossing the North Branch Lamoille River, Belvidere, Vermont.

[VTAOT, Vermont Agency of Transportation; --, no data]

\begin{tabular}{|c|c|c|c|c|c|c|c|c|c|c|c|}
\hline Description & Station $^{1}$ & $\begin{array}{l}\text { VTAOT } \\
\text { minimum } \\
\text { low-chord } \\
\text { elevation } \\
\text { (feet) }\end{array}$ & $\begin{array}{l}\text { Surveyed } \\
\text { minimum } \\
\text { low-chord } \\
\text { elevation } \\
\quad \text { (feet) }\end{array}$ & $\begin{array}{l}\text { Bottom of } \\
\text { footing } \\
\text { elevation } \\
\text { (feet) }\end{array}$ & $\begin{array}{c}\text { Channel } \\
\text { elevation at } \\
\text { abutment/ } \\
\text { pier }^{2} \\
\text { (feet) }\end{array}$ & $\begin{array}{l}\text { Contraction } \\
\text { scour depth } \\
\text { (feet) }\end{array}$ & $\begin{array}{l}\text { Abutment } \\
\text { scour } \\
\text { depth } \\
\text { (feet) }\end{array}$ & $\begin{array}{l}\text { Pier } \\
\text { scour } \\
\text { depth } \\
\text { (feet) }\end{array}$ & $\begin{array}{l}\text { Depth of } \\
\text { total scour } \\
\text { (feet) }\end{array}$ & $\begin{array}{c}\text { Elevation of } \\
\text { scour }^{2} \\
\text { (feet) }\end{array}$ & $\begin{array}{c}\text { Remaining } \\
\text { footing/pile } \\
\text { depth } \\
\text { (feet) }\end{array}$ \\
\hline \multicolumn{12}{|c|}{500 -year discharge is 5,400 cubic-feet per second } \\
\hline Left abutment & 0.0 & -- & 498.2 & -- & 488.2 & 0.9 & 13.8 & -- & 14.7 & 473.5 & -- \\
\hline Right abutment & 32.7 & -- & 498.0 & -- & 489.3 & 0.9 & 22.2 & -- & 23.1 & 466.2 & -- \\
\hline
\end{tabular}

1.Measured along the face of the most constricting side of the bridge.

2.Arbitrary datum for this study. 


\section{SELECTED REFERENCES}

Arcement, G.J., Jr., and Schneider, V.R., 1989, Guide for selecting Manning's roughness coefficients for natural channels and flood plains: U.S. Geological Survey Water-Supply Paper 2339, 38 p.

Barnes, H.H., Jr., 1967, Roughness characteristics of natural channels: U.S. Geological Survey Water-Supply Paper 1849,213 p.

Benson, M. A., 1962, Factors Influencing the Occurrence of Floods in a Humid Region of Diverse Terrain: U.S. Geological Survey WaterSupply Paper 1580-B, 64 p.

Brown, S.A. and Clyde, E.S., 1989, Design of riprap revetment: Federal Highway Administration Hydraulic Engineering Circular No. 11, Publication FHWA-IP-89-016, 156 p.

Federal Highway Administration, 1983, Runoff estimates for small watersheds and development of sound design: Federal Highway Administration Report FHWA-RD-77-158.

Federal Highway Administration, 1993, Stream Stability and Scour at Highway Bridges: Participant Workbook: Federal Highway Administration Report FHWA-HI-91-011.

Froehlich, D.C., 1989, Local scour at bridge abutments in Ports, M.A., ed., Hydraulic Engineering--Proceedings of the 1989 National Conference on Hydraulic Engineering: New York, American Society of Civil Engineers, p. 13-18.

Hayes, D.C.,1993, Site selection and collection of bridge-scour data in Delaware, Maryland, and Virginia: U.S. Geological Survey WaterResources Investigation Report 93-4017, 23 p.

Interagency Advisory Committee on Water Data, 1982, Guidelines for determining flood flow frequency: U.S. Geological Survey, Bulletin 17B of the Hydrology Subcommittee, 190 p.

Johnson, C.G. and Tasker, G.D.,1974, Progress report on flood magnitude and frequency of Vermont streams: U.S. Geological Survey OpenFile Report 74-130, 37 p.

Lagasse, P.F., Schall, J.D., Johnson, F., Richardson, E.V., Chang, F., 1995, Stream Stability at Highway Structures: Federal Highway Administration Hydraulic Engineering Circular No. 20, Publication FHWA-IP-90-014, 144 p.

Laursen, E.M., 1960, Scour at bridge crossings: Journal of the Hydraulics Division, American Society of Civil Engineers, v. 86, no. HY2, p. 39-53.

Potter, W. D., 1957, Peak rates of runoff in the New England Hill and Lowland area, Bureau of Public Roads

Richardson, E.V. and Davis, S.R., 1995, Evaluating scour at bridges: Federal Highway Administration Hydraulic Engineering Circular No. 18, Publication FHWA-IP-90-017, 204 p.

Richardson, E.V., Simons, D.B., and Julien, P.Y., 1990, Highways in the river environment: Federal Highway Administration Publication FHWA-HI-90-016.

Ritter, D.F., 1984, Process Geomorphology: W.C. Brown Co., Debuque, Iowa, 603 p.

Shearman, J.O., 1990, User's manual for WSPRO--a computer model for water surface profile computations: Federal Highway Administration Publication FHWA-IP-89-027, 187 p.

Shearman, J.O., Kirby, W.H., Schneider, V.R., and Flippo, H.N., 1986, Bridge waterways analysis model; research report: Federal Highway Administration Publication FHWA-RD-86-108, 112 p.

Talbot, A.N., 1887, The determination of water-way for bridges and culverts.

U.S. Geological Survey, 1986, Cold Hollow Mountains, Vermont 7.5 Minute Series quadrangle map: U.S. Geological Survey Topographic Maps; Aerial photographs, 1980; Contour interval, 6 meters; Scale 1:24,000.

U.S. Geological Survey, 1986, Johnson, Vermont 7.5 Minute Series quadrangle map: U.S. Geological Survey Topographic Maps; Aerial photographs, 1981; Contour interval, 6 meters; Scale, 1:24,000 


\section{APPENDIX A: \\ WSPRO INPUT FILE}




\section{WSPRO INPUT FILE}

GR

GR

$\mathrm{N}$

SA

*

X

*

BR

GR

GR

GR

GR

GR

*

$\mathrm{CD}$

$\mathrm{N}$

*

XR

GR

GR

$\mathrm{XT}$

GR

GR

GR

GR

GR

AS

GT

$\mathrm{N}$

SA

HP 1 BRIDG 493.71 1 493.71

HP 2 BRIDG 493.71 * * 3650

HP 1 APPRO 498.411498 .41

HP 2 APPRO 498.41 * * 3650

HP 1 BRIDG 498.11 1498.11

HP 2 BRIDG 498.11 * * 4348

HP 2 BRIDG 495.11 * * 4348

HP 2 RDWAY 501.48 * * 1050

HP 1 APPRO 501.72 1501.72

HP 2 APPRO 501.72 * * 5400

\section{*}

HP 1 BRIDG $493.74 \quad 1 \quad 493.74$

HP 2 BRIDG 493.74 * *3670

HP 1 APPRO 498.451498 .45

HP 2 APPRO 498.45 * * 3670

\section{*}

EX ER

$\begin{array}{rrrr}0.1,496.52 & 1.1,496.46 & 2.4,488.21 \\ 8.1,486.16 & 8.5,484.36 & 11.6,484.71 \\ 15.3,483.11 & 18.2,483.63 & 23.6,485.42 \\ 28.9,487.93 & 32.1,489.29 & 32.7,498.02\end{array}$

$28.9,487.93$

$-6.0,493.59$

$38.0,484.89$

$13.1,486.16$

$52.7,488.94$

$63.4,496.03$

$32.7,498.02$
$-13.1,499.32$

$28.9,484.15$

$54.0,491.77$

Date: 22 -MAY-97

63.4

0.055
$-81.7,500.22$

$218.1,514.08$

$-120.9,497.82$

$-72.5,497.93$

$10.1,487.80$

$39.6,490.25$
$-44.3,499.31$

$-117.2,498.79$

$-13.8,496.36$

$21.8,486.34$

$52.2,492.61$
$0.0,488.72$

$34.5,487.82$

0.0536

0.055 


\section{APPENDIX B: \\ WSPRO OUTPUT FILE}


WSPRO OUTPUT FILE

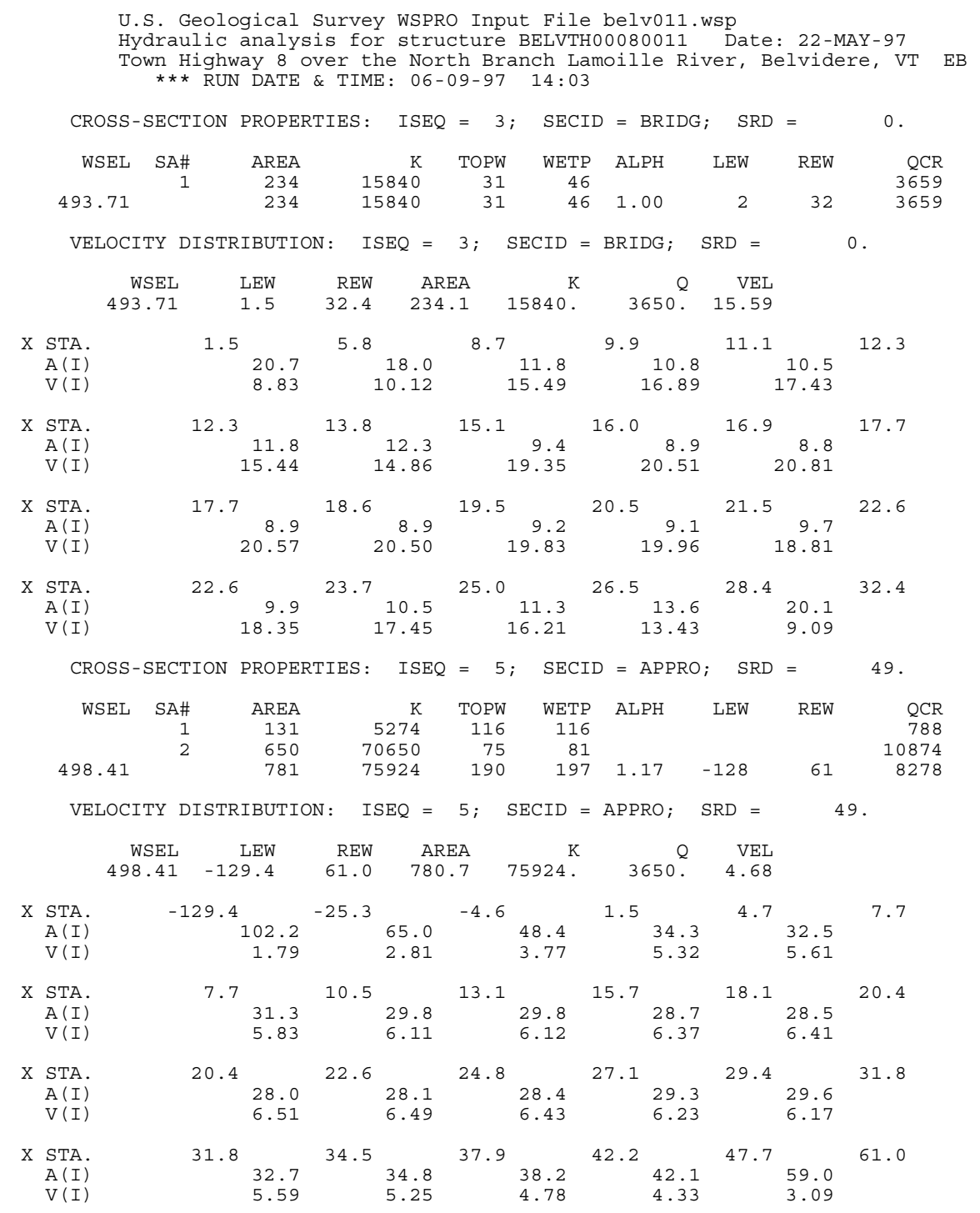




\section{WSPRO OUTPUT FILE (continued)}

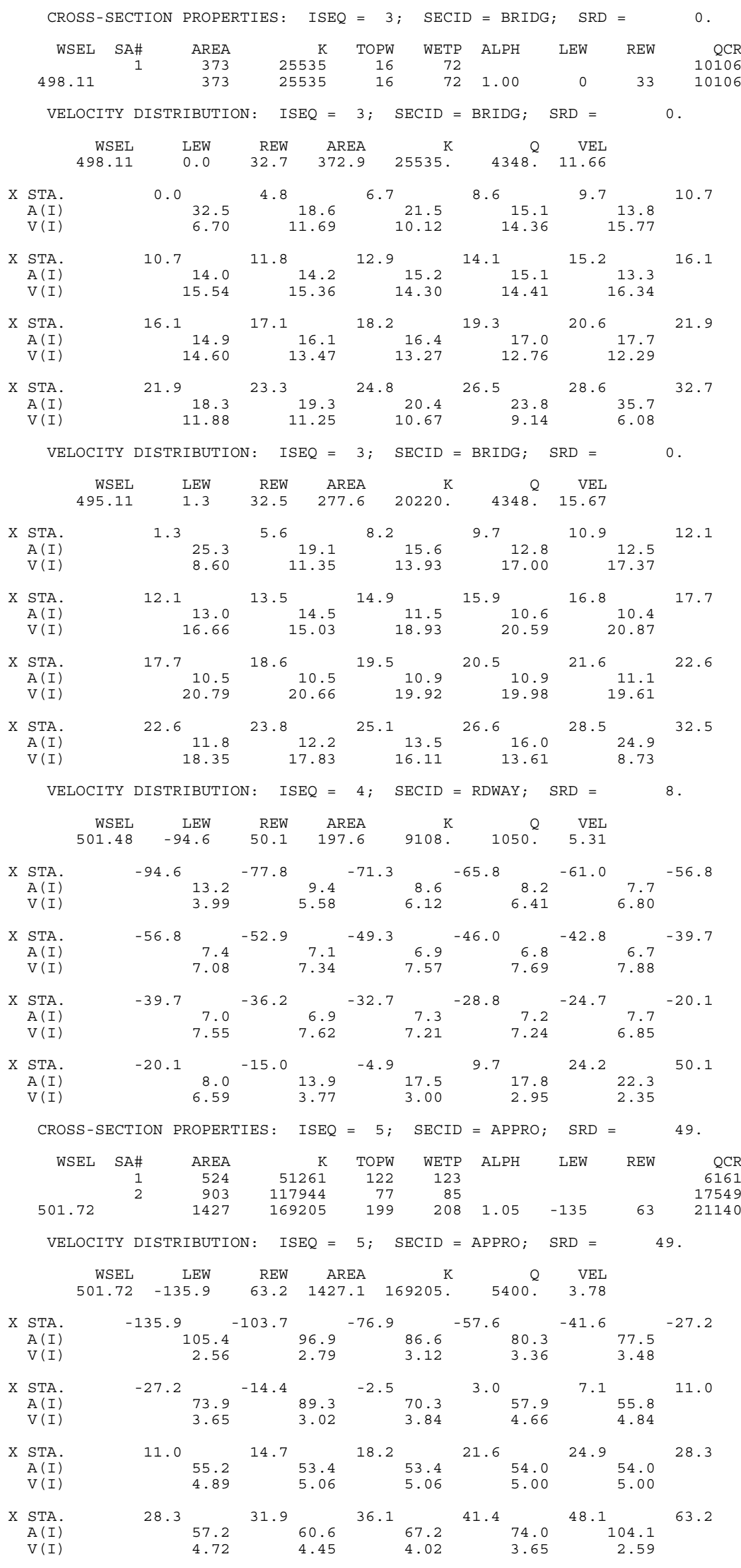


WSPRO OUTPUT FILE (continued)

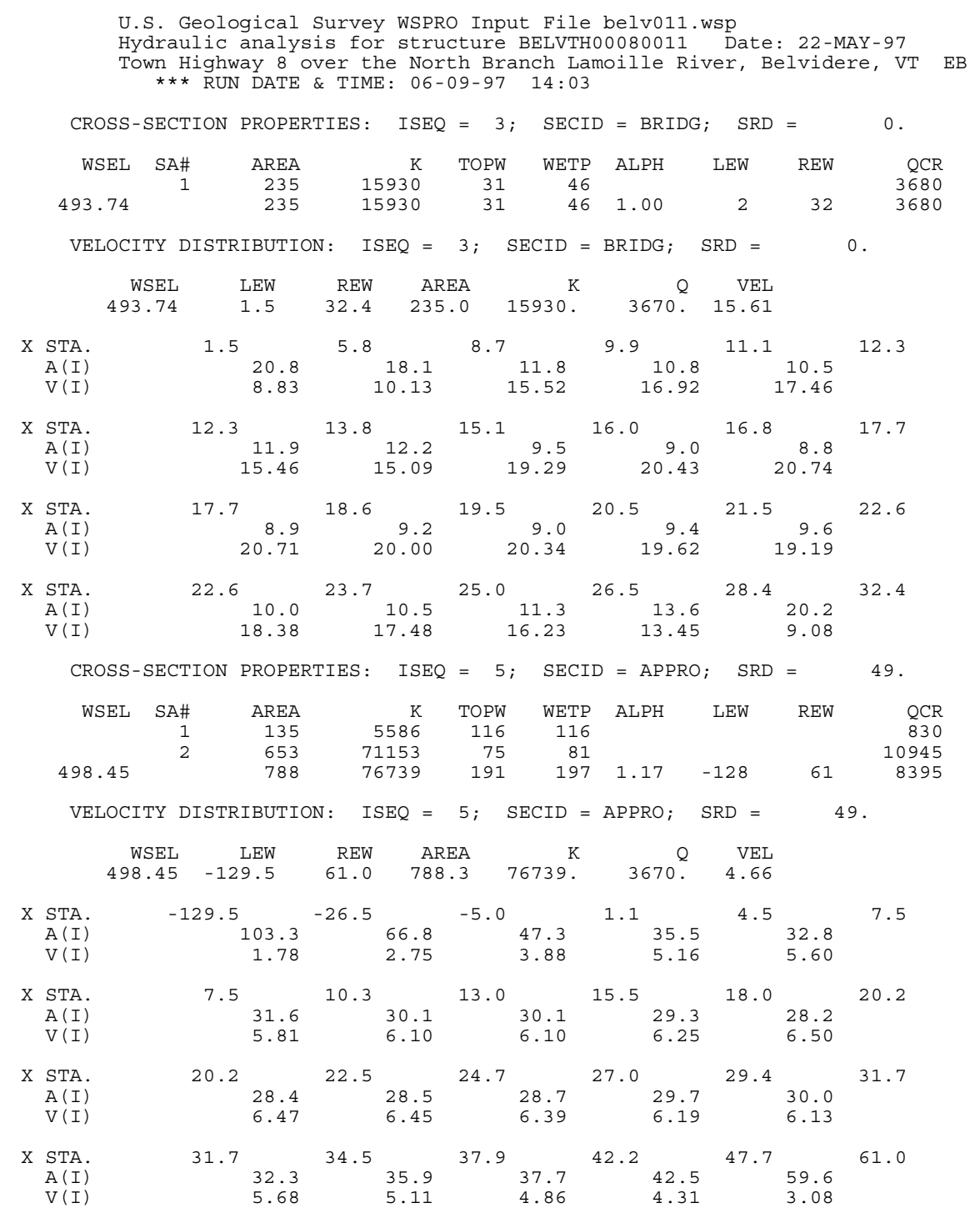


WSPRO OUTPUT FILE (continued)

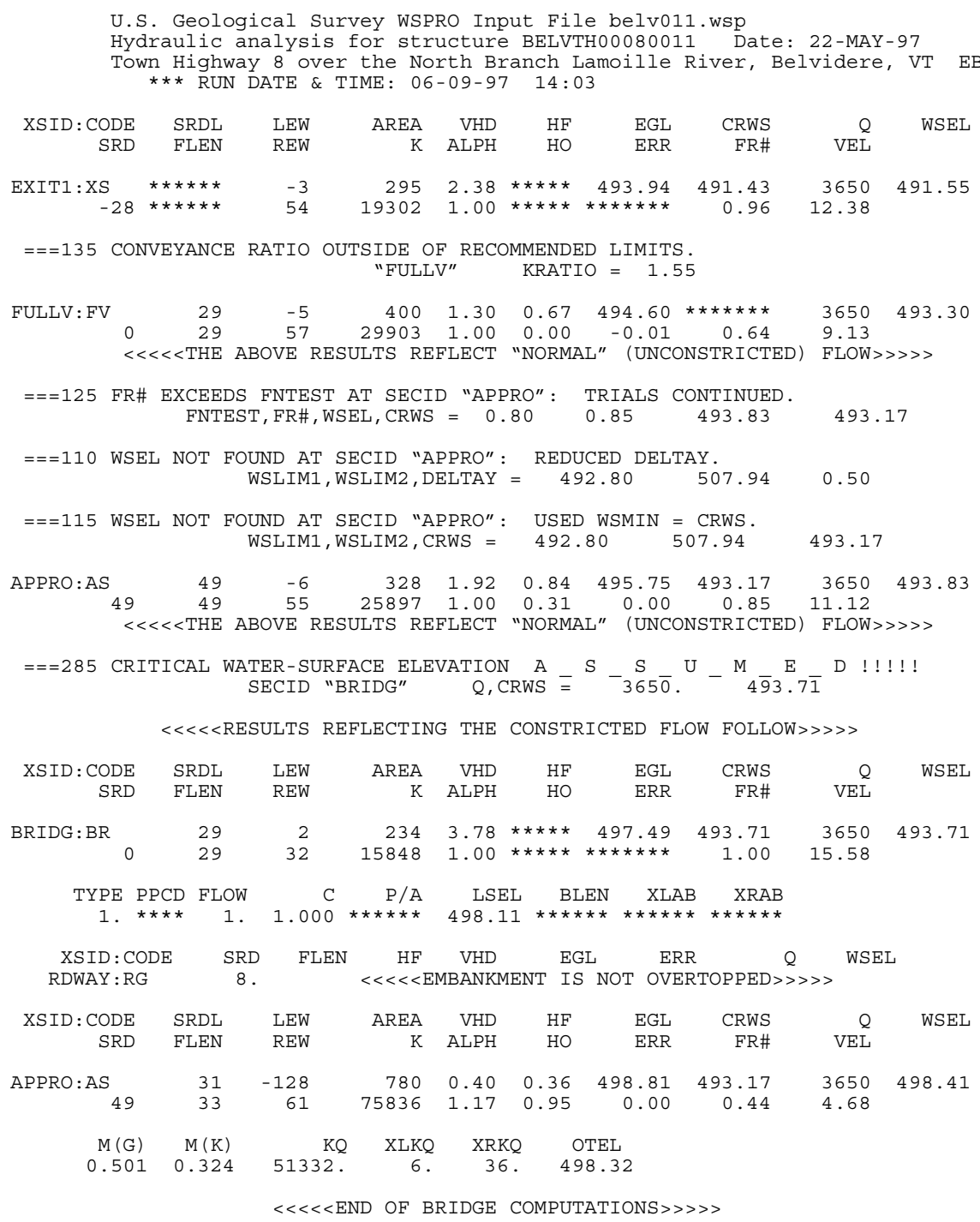

FIRST USER DEFINED TABLE.

\begin{tabular}{|c|c|c|c|c|c|c|c|c|}
\hline XSID: CODE & SRD & LEW & REW & $Q$ & K & AREA & VEL & WSEL \\
\hline EXIT1:XS & -29 & -4 . & 54. & 3650. & 19302. & 295. & 12.38 & 491.55 \\
\hline FULLV : FV & 0 . & -6 & 57. & 3650 . & 29903 . & 400 & 9.13 & 493.30 \\
\hline BRIDG : BR & 0 . & 2 . & 32 . & 3650 . & 15848 . & 234. & 15.58 & 493.71 \\
\hline RDWAY : RG & \multicolumn{3}{|c|}{$8 . * * * * \star * * * * * * * * *$} & \multicolumn{3}{|c|}{$0 . * * * * * * * * * * * * \star * * * * * *$} & \multicolumn{2}{|c|}{$2.00 * * * * * * * *$} \\
\hline APPRO : AS & 49 . & -129. & 61. & 3650 . & 75836 . & 780. & 4.68 & 498.41 \\
\hline XSID : CODE & XLKQ & XRKQ & & & & & & \\
\hline APPRO : AS & 6. & 36. & 5133 & & & & & \\
\hline
\end{tabular}

SECOND USER DEFINED TABLE.

\begin{tabular}{|c|c|c|c|c|c|c|c|c|c|}
\hline XSID : CODE & CRWS & FR\# & YMIN & YMAX & $\mathrm{HF}$ & $\mathrm{HO}$ & VHD & EGL & \\
\hline XI & 491 & & 84 & 12. & $\approx * \star * \star *$ & 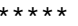 & & 4 & \\
\hline UI & $\approx * \star \star \star \star * \star$ & & & 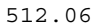 & 0.67 & 0.00 & & 0 & \\
\hline 3RI & 493.71 & & 3 . & $0 *$ & $\star * \star * \star * *$ & $\star \star \star \star * *$ & 3.78 & 497.49 & \\
\hline & $\star * *$ & & & & $* * *$ & $* * x$ & & & \\
\hline $0: A S$ & 493.17 & 0.44 & 85.75 & 07.94 & 0.36 & 0.95 & 0.40 & 498.81 & \\
\hline
\end{tabular}


WSPRO OUTPUT FILE (continued)

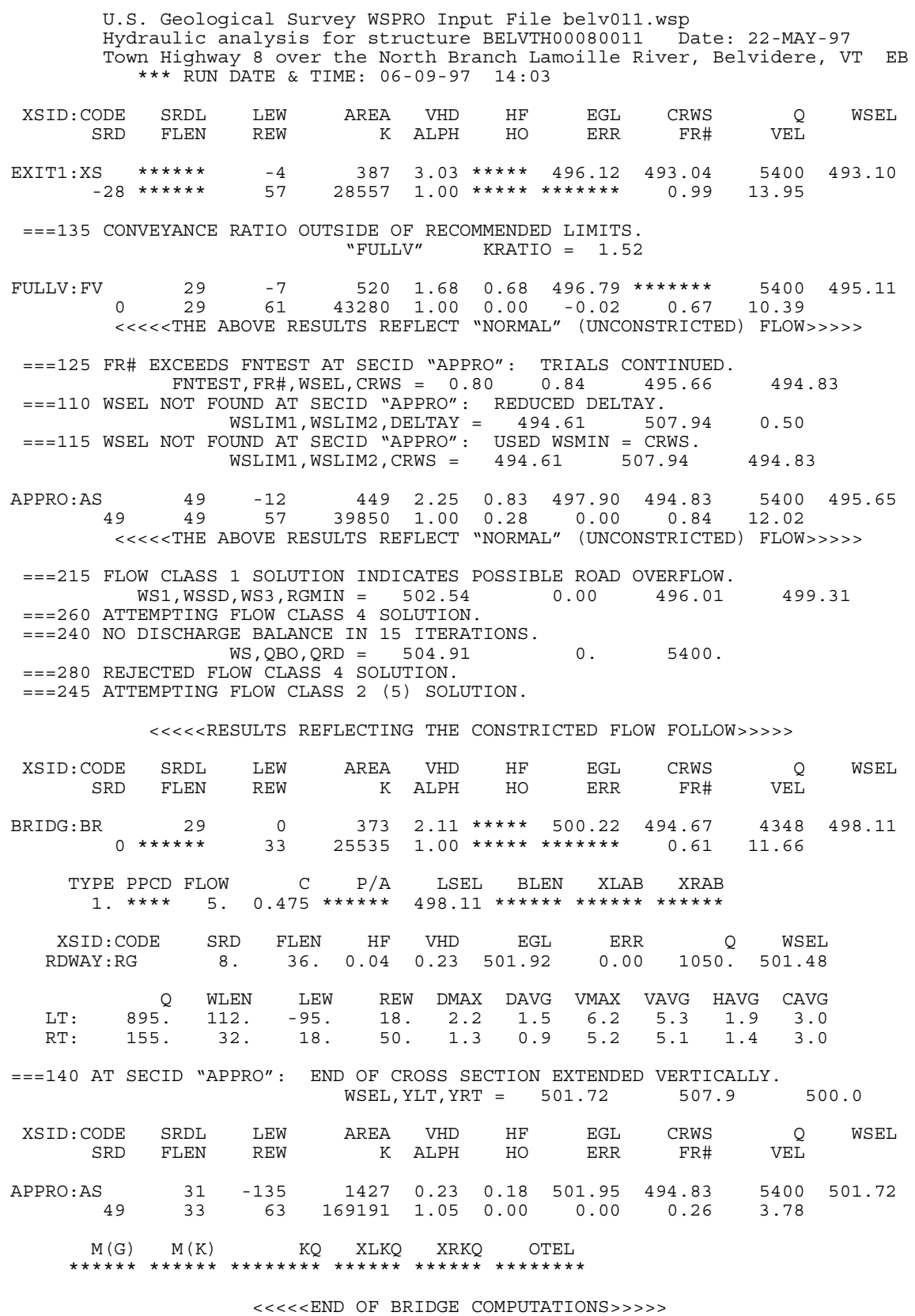

FIRST USER DEFINED TABLE.

\begin{tabular}{|c|c|c|c|c|c|c|c|c|}
\hline XSID : CODE & SRD & LEW & REW & c & $\mathrm{K}$ & AREA & VEL & WSEL \\
\hline EXIT1:XS & -29. & -5 & 57. & 5400 & 28557 . & 387. & 13.95 & 493.10 \\
\hline FULLV : FV & 0 . & -8 & 61. & 5400 & 43280 . & 520. & 10.39 & 495.11 \\
\hline BRIDG : BR & 0 . & 0. & 33. & 4348 & 25535 . & 373. & 11.66 & 498.11 \\
\hline RDWAY : RG & 8 . & $\star \star \star \star \star \star *$ & 895. & 1050 & 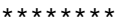 & $\star \star \star \star \star \star *$ & 2.00 & 501.48 \\
\hline APPRO: AS & 49. & -136 & 63. & 5400 & 169191. & 1427. & 3.78 & 501.72 \\
\hline SID : CODE & LKQ & XRKQ & & & & & & \\
\hline
\end{tabular}

SECOND USER DEFINED TABLE.

$\begin{array}{lcrrrrrrrr}\text { XSID:CODE } & \text { CRWS } & \text { FR\# } & \text { YMIN } & \text { YMAX } & \text { HF } & \text { HO } & \text { VHD } & \text { EGL } & \text { WSEL } \\ \text { EXITI:XS } & 493.04 & 0.99 & 484.15 & 512.06 * * * * * * * * * * * & 3.03 & 496.12 & 493.10 \\ \text { FULLV:FV } & * * * * * * * & 0.67 & 484.15 & 512.06 & 0.68 & 0.00 & 1.68 & 496.79 & 495.11 \\ \text { BRIDG :BR } & 494.67 & 0.61 & 483.11 & 498.20 * * * * * * * * * * & 2.11 & 500.22 & 498.11 \\ \text { RDWAY:RG } & * * * * * * * * * * * * * * & 499.31 & 527.30 & 0.04 * * * * * * & 0.23 & 501.92 & 501.48 \\ \text { APPRO:AS } & 494.83 & 0.26 & 485.75 & 507.94 & 0.18 & 0.00 & 0.23 & 501.95 & 501.72\end{array}$


WSPRO OUTPUT FILE (continued)

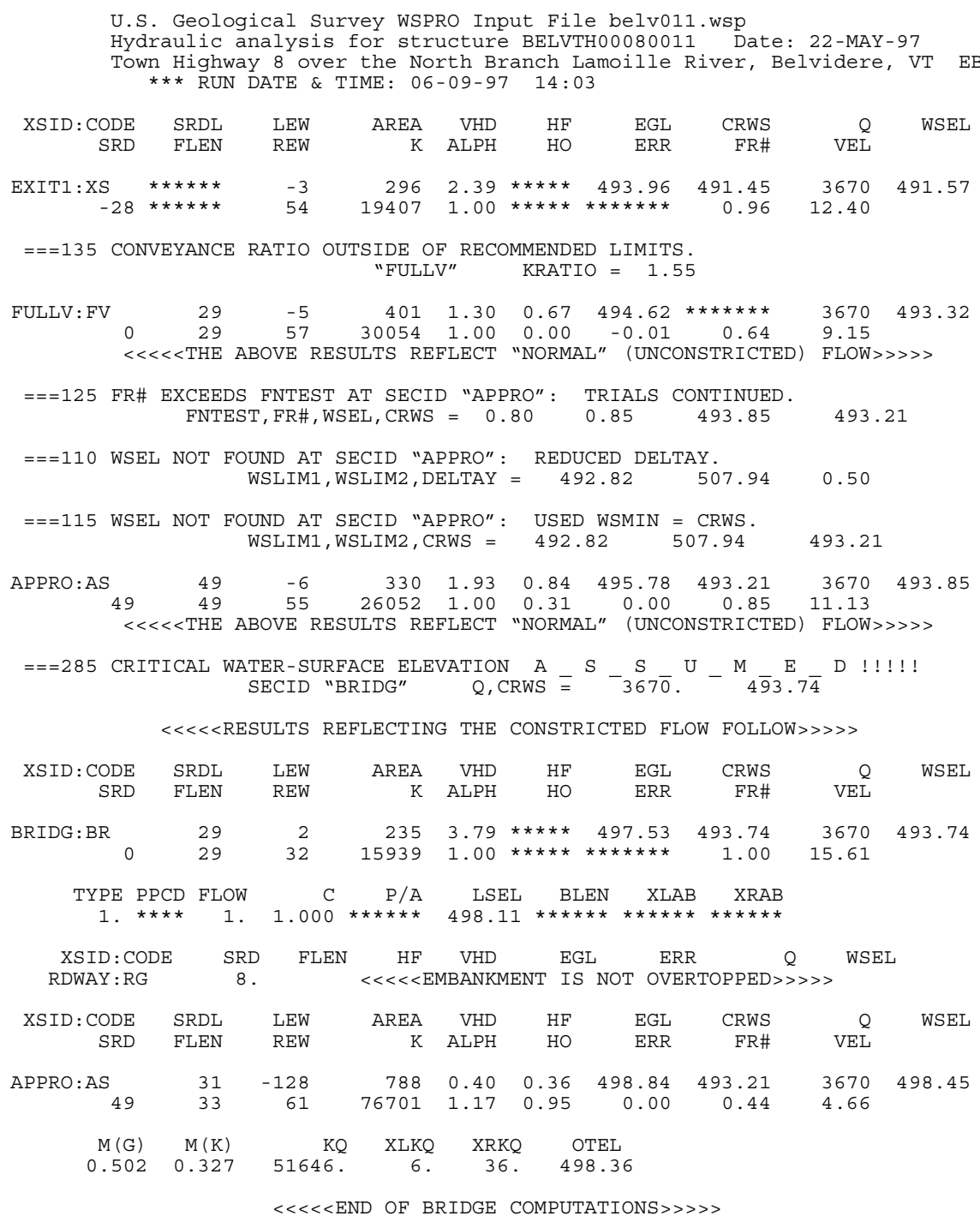

FIRST USER DEFINED TABLE.

\begin{tabular}{|c|c|c|c|c|c|c|c|c|}
\hline XSID : CODE & SRD & LEW & REW & $c$ & $\mathrm{r}$ & AREA & VEL & WSEL \\
\hline EXIT1:XS & -29 & -4 . & 54. & 3670. & 19407. & 296. & 12.40 & 491.57 \\
\hline FULLV : FV & 0 . & -6 . & 57. & 3670. & 30054 & 401. & 9.15 & 493.32 \\
\hline BRIDG : BR & 0 . & 2 . & 32. & 3670 & 15939. & 235. & 15.61 & 493.74 \\
\hline RDWAY : RG & 8 . & $\approx * \star \star \star \star *$ & $\star \star \star \star \star *$ & 0 . & $* \star \star *$ & $\star \star \star \star \star *$ & 2.00 & 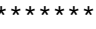 \\
\hline APPRO:AS & 49. & -129. & 61. & 3670. & 76701 & 788. & 4.66 & 498.45 \\
\hline XSID : CODE & XLKQ & XRKQ & & & & & & \\
\hline APPRO : AS & 6. & 36. & 5164 & & & & & \\
\hline
\end{tabular}

SECOND USER DEFINED TABLE.

\begin{tabular}{|c|c|c|c|c|c|c|c|c|c|}
\hline XSID : CODE & CRWS & FR\# & YMIN & YMAX & $\mathrm{HF}$ & $\mathrm{HO}$ & VHD & EGL & WSEL \\
\hline EXIT1:XS & 491.45 & 0.96 & 484.15 & $512.06 *$ & $\star \star \star \star \star * *$ & $\star \star \star \star \star *$ & 2.39 & 493.96 & 491.57 \\
\hline FULLV : FV & $\star * \star * \star * * *$ & 0.64 & 484.15 & 512.06 & 0.67 & 0.00 & 1.30 & 494.62 & 493.32 \\
\hline BRIDG : BR & 493.74 & 1.00 & 483.11 & $498.20 * x$ & $\star * \star * * *$ & $\star \star \star \star * *$ & 3.79 & 497.53 & 493.74 \\
\hline RDWAY : RG & 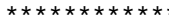 & $\star \star \star \star \star *$ & 499.31 & $527.30 *$ & $\star \star \star \star * * *$ & $\star \star \star \star \star * *$ & 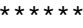 & $\star \star \star \star \star * \star * \star *$ & $\star \star \star \star \star \star * \star *$ \\
\hline APPRO:AS & 493.21 & 0.44 & 485.75 & 507.94 & 0.36 & 0.95 & 0.40 & 498.84 & 498.45 \\
\hline
\end{tabular}




\section{APPENDIX C:}

\section{BED-MATERIAL PARTICLE-SIZE DISTRIBUTION}




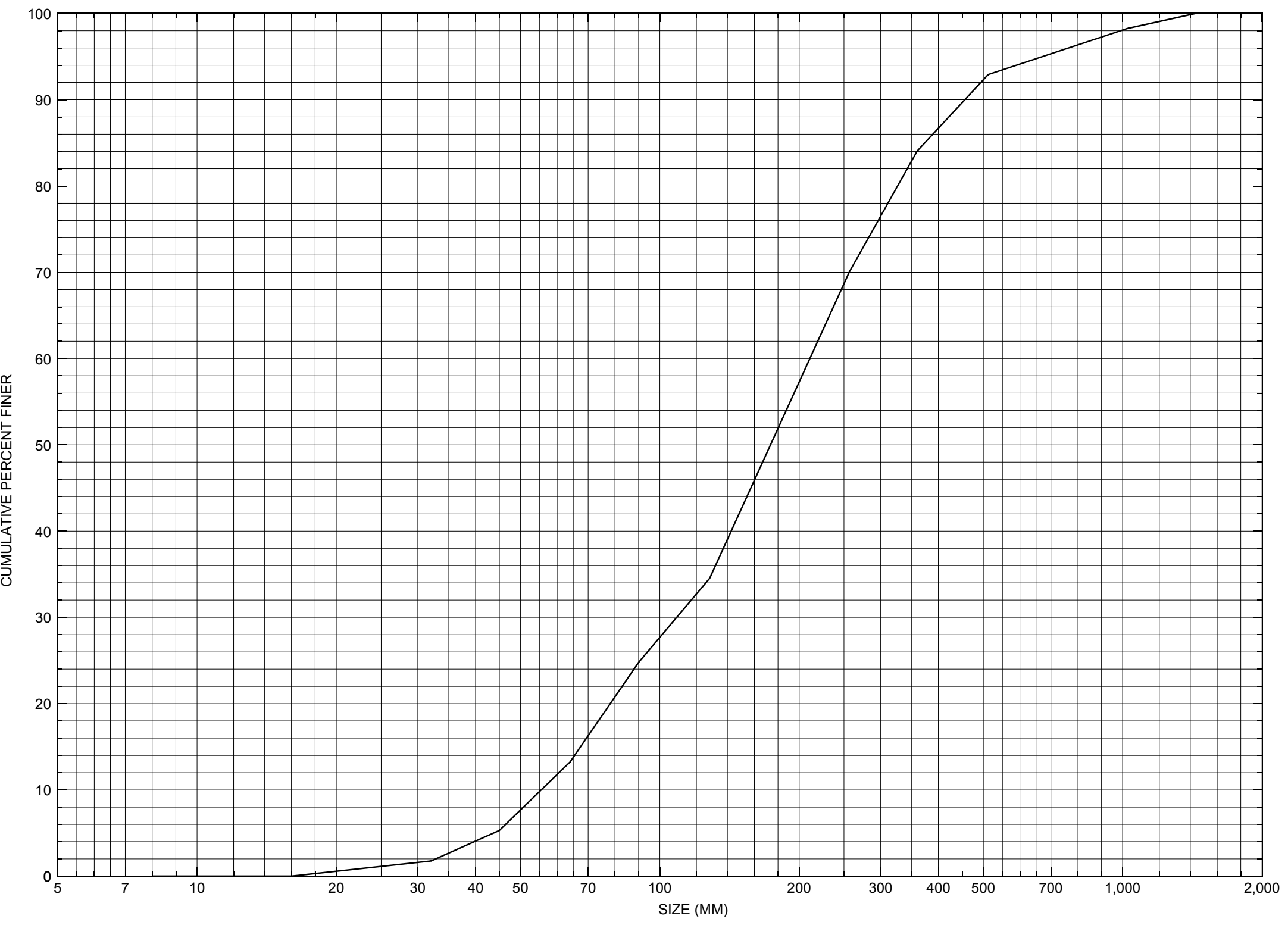

Appendix C. Bed material particle-size distribution for a pebble count in the channel approach of structure BELVTH00080011, in Belvidere, Vermont. 


\section{APPENDIX D: \\ HISTORICAL DATA FORM}




\section{Structure Number BELVTH00080011}

\section{General Location Descriptive}

Data collected by (First Initial, Full last name) $\mathbf{E}$. BOEHMLER

Date $(M M / D D / Y Y) \_\mathbf{0 3} / \underline{\mathbf{0 7}} / \underline{\mathbf{9 5}}$

Highway District Number $(I-2 ; n n) \underline{\mathbf{0 8}}$

Town (FIPS place code; I - 4; nnnnn) $\mathbf{0 4 3 7 5}$

Waterway (I - 6) North Branch Lamoille River

Route Number $\underline{\text { TH } 8}$

Topographic Map Cold Hollow Mountains

Latitude (I - 16; nnnn.n) $\mathbf{4 4 4 5 1}$
County (FIPS county code; I - 3; nnn)

Mile marker (I - 11; nnn.nnn) $\mathbf{0 0 0 0 0 0}$

Road Name (I - 7): -

Vicinity (I - 9) $\mathbf{0 . 0 5}$ MI JCT TH 8 + VT109

Hydrologic Unit Code: $\mathbf{0 2 0 1 0 0 0 5}$

Longitude (i - 17; nnnnn.n) $\mathbf{7 2 4 1 1}$

\section{Select Federal Inventory Codes}

FHWA Structure Number $(I$ - 8) 10080100110801

Maintenance responsibility $(I-21 ; n n) \quad \mathbf{0 3}$

Year built (I - 27; YYYY) 1919

Average daily traffic, ADT (I - 29; nnnnnn) 000050

Year of ADT (I - 30; YY) $\mathbf{9 3}$

Opening skew to Roadway $(I-34 ; n n) \quad \mathbf{0 0}$

Operational status $(I-41 ; X) \mathbf{R}$

Structure type (I - 43; nnn) $\mathbf{3 0 2}$

Approach span structure type (I - 44; nnn) $\mathbf{0 0 0}$

Number of spans (I - 45; nnn) $\mathbf{0 0 1}$

Number of approach spans (I - 46; nnnn) $\mathbf{0 0 0 0}$

Comments:

The structural inspection report of $6 / 21 / 93$ indicates the structure is a steel stringer type bridge with a concrete deck. The abutments are "laid-up" stone with concrete caps. The wingwalls are also "laid-up" stone. The left abutment, the downstream left wingwall and a portion of the upstream left wingwall all have concrete facings. Boulder material along the base of the left abutment has been encased in the concrete facing. The right abutment has some free-poured concrete along its bottom. A few boulders under the right abutment have slid out from underneath creating voids, above which several stones of the abutment are cracked or broken. A few large boulders are present in front of both (Continued, page 33) 


\section{Bridge Hydrologic Data}

Is there hydrologic data available? $\underline{\mathbf{N}}$ if No, type ctrl-n $h \quad$ VTAOT Drainage area $\left(m i^{2}\right)$ : -

Terrain character:

Stream character \& type: -

Streambed material:

Discharge Data (cfs):

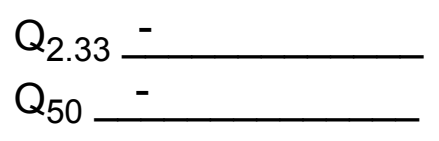

Record flood date $(M M / D D / Y Y):-{ }^{\prime}-$
Estimated Discharge $(c f s):-$

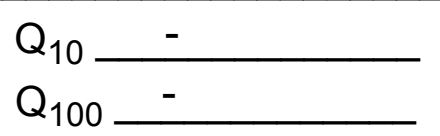

$\mathrm{Q}_{25}$

Water surface elevation $(f t):-$ $(\mathrm{ft} / \mathrm{s}):$

Ice conditions (Heavy, Moderate, Light) : -

Debris (Heavy, Moderate, Light):

The stage increases to maximum highwater elevation (Rapidly, Not rapidly):

The stream response is (Flashy, Not flashy):

Describe any significant site conditions upstream or downstream that may influence the stream's stage: -

Watershed storage area (in percent):

The watershed storage area is: - (1-mainly at the headwaters; 2- uniformly distributed; 3-immediatly upstream oi the site)

Water Surface Elevation Estimates for Existing Structure:

\begin{tabular}{|l|l|l|l|l|l|}
\hline Peak discharge frequency & $Q_{2.33}$ & $Q_{10}$ & $Q_{25}$ & $Q_{50}$ & $Q_{100}$ \\
Water surface elevation (ft)) & - & - & - & - & - \\
Velocity (ft/sec) & - & - & - & - & - \\
\hline
\end{tabular}

Long term stream bed changes: -

Is the roadway overtopped below the $\mathrm{Q}_{100}$ ? (Yes, No, Unknown): $\mathbf{U}$ Frequency: -

Relief Elevation (ft):

Discharge over roadway at $Q_{100}\left(f^{3} / \mathrm{sec}\right)$ :

Are there other structures nearby? (Yes, No, Unknown): If No or Unknown, type ctrl-n os Upstream distance (miles): Town: Year Built:

Highway No. : Structure No. : -

Clear span (ft): Clear Height $(f t)$ : Full Waterway $\left(f^{2}\right)$ : 
Downstream distance (miles): Town: Year Built:

Highway No. : Structure No. : Structure Type:

Clear span (ft): Clear Height $(f t)$ : Full Waterway $\left(f t^{2}\right)$ :

Comments:

abutment walls and all of the wingwalls. Additional riprap protection is noted along the up- and downstream banks.

\section{USGS Watershed Data}

Watershed Hydrographic Data

Drainage area $(D A) \stackrel{23.41}{2 \mathrm{mi}^{2}}$

Watershed storage (ST) $\quad \mathbf{3 . 0}$

Bridge site elevation

Main channel length 925 10 $10 \%$ channel length elevation

Main channel slope

(S) 110.67 $\mathrm{ft} / \mathrm{mi}$ $\%$ mi

Lake/pond/swamp area

0.71 $\mathrm{mi}^{2}$

Headwater elevation 2999 $\mathrm{ft}$ $\mathrm{ft} \quad 85 \%$ channel length elevation $\mathrm{ft}$

Watershed Precipitation Data

Average site precipitation in Average headwater precipitation in

Maximum 2yr-24hr precipitation event $(124,2)$ in

Average seasonal snowfall (Sn) $\mathrm{ft}$ 


\section{Bridge Plan Data}

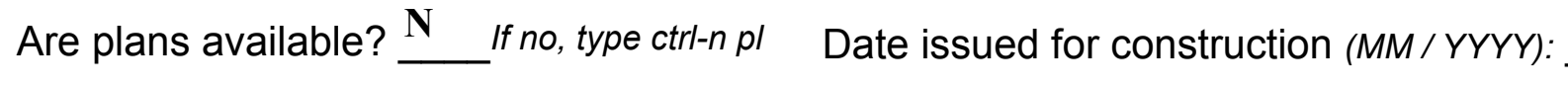

Project Number -

Minimum channel bed elevation:

Low superstructure elevation: USLAB DSLAB USRAB DSRAB Benchmark location description:

NO BENCHMARK INFORMATION

Reference Point (MSL, Arbitrary, Other): Datum (NAD27, NAD83, Other):

Foundation Type: $\mathbf{3}$

If 1: Footing Thickness

If 2: Pile Type: (1-Wood; 2-Steel or metal; 3-Concrete)

(1-Spreadfooting; 2-Pile; 3- Gravity; 4-Unknown)

Footing bottom elevation:

If 3 : Footing bottom elevation:

Is boring information available? $\mathbf{N}$ If no, type ctrl-n bi Approximate pile driven length:

Foundation Material Type: 3 (1-regolith, 2-bedrock, 3-unknown)

Briefly describe material at foundation bottom elevation or around piles:

NO FOUNDATION MATERIAL INFORMATION

Comments:

$-$ 


\section{Cross-sectional Data}

Is cross-sectional data available? $\underline{\mathbf{Y}}$ If no, type ctrl-n xs

Source (FEMA, VTAOT, Other)? FEMA Comments:

The low cord elevations and the bed elevations were retrieved from the FEMA cross sections.

\begin{tabular}{|l|l|l|l|l|l|l|l|l|l|l|l|}
\hline Station & 200 & 200.1 & 205 & 213 & 221 & 227 & 228 & 233 & 233.1 & - & - \\
\hline Feature & LB & & & & & & & & RB & - & - \\
\hline $\begin{array}{l}\text { Low cord } \\
\text { elevation }\end{array}$ & $\mathbf{8 9 5 . 3}$ & $\mathbf{9 0 4 . 8}$ & $\mathbf{9 0 4 . 8}$ & $\mathbf{9 0 4 . 8}$ & $\mathbf{9 0 4 . 8}$ & $\mathbf{9 0 4 . 8}$ & $\mathbf{9 0 4 . 8}$ & $\mathbf{9 0 4 . 8}$ & $\mathbf{8 9 5 . 9}$ & - & - \\
\hline $\begin{array}{l}\text { Bed } \\
\text { elevation }\end{array}$ & $\mathbf{8 9 5 . 3}$ & $\mathbf{8 9 5 . 3}$ & $\mathbf{8 9 3 . 6}$ & $\mathbf{8 9 2 . 4}$ & $\mathbf{8 9 1 . 6}$ & $\mathbf{8 9 2 . 6}$ & $\mathbf{8 9 3 . 6}$ & $\mathbf{8 9 5 . 9}$ & $\mathbf{8 9 5 . 9}$ & - & - \\
\hline $\begin{array}{l}\text { Low cord to } \\
\text { bed length }\end{array}$ & $\mathbf{0}$ & $\mathbf{9 . 5}$ & $\mathbf{1 1 . 2}$ & $\mathbf{1 2 . 4}$ & $\mathbf{1 3 . 2}$ & $\mathbf{1 2 . 2}$ & $\mathbf{1 1 . 2}$ & $\mathbf{8 . 9}$ & $\mathbf{0}$ & - & - \\
\hline Station & - & - & - & - & - & - & - & - & - & - & - \\
\hline Feature & - & - & - & - & - & - & - & - & - & - & - \\
\hline $\begin{array}{l}\text { Low cord } \\
\text { elevation }\end{array}$ & - & - & - & - & - & - & - & - & - & - & - \\
\hline $\begin{array}{l}\text { Bed } \\
\text { elevation }\end{array}$ & - & - & - & - & - & - & - & - & - & - & - \\
\hline $\begin{array}{l}\text { Low cord to } \\
\text { bed length }\end{array}$ & - & - & - & - & - & - & - & - & - & - & - \\
\hline
\end{tabular}

Source (FEMA, VTAOT, Other)?

Comments:

\begin{tabular}{|l|l|l|l|l|l|l|l|l|l|l|l|}
\hline Station & - & - & - & - & - & - & - & - & - & - & - \\
\hline Feature & - & - & - & - & - & - & - & - & - & - & - \\
\hline $\begin{array}{l}\text { Low cord } \\
\text { elevation }\end{array}$ & - & - & - & - & - & - & - & - & - & - & - \\
\hline $\begin{array}{l}\text { Bed } \\
\text { elevation }\end{array}$ & - & - & - & - & - & - & - & - & - & - & - \\
\hline $\begin{array}{l}\text { Low cord to } \\
\text { bed length }\end{array}$ & - & - & - & - & - & - & - & - & - & - & - \\
\hline Station & - & - & - & - & - & - & - & - & - & - & - \\
\hline Feature & - & - & - & - & - & - & - & - & - & - & - \\
\hline $\begin{array}{l}\text { Low cord } \\
\text { elevation }\end{array}$ & - & - & - & - & - & - & - & - & - & - & - \\
\hline $\begin{array}{l}\text { Bed } \\
\text { elevation }\end{array}$ & - & - & - & - & - & - & - & - & - & - & - \\
\hline $\begin{array}{l}\text { Low cord to } \\
\text { bed length }\end{array}$ & - & - & - & - & - & - & - & - & - & - & - \\
\hline
\end{tabular}




\section{APPENDIX E: \\ LEVEL I DATA FORM}


U. S. Geological Survey

Bridge Field Data Collection and Processing Form

Qa/Qc Check by: $\underline{\mathbf{R B}}$ Date: $\underline{\mathbf{0 3} / \mathbf{1 5} / \mathbf{9 6}}$

\section{Structure Number}

\section{A. General Location Descriptive}

1. Data collected by (First Initial, Full last name) $\underline{\text { J }}$. DEGNAN

2. Highway District Number $\mathbf{0 8}$

County LAMOILLE (015)

Waterway (I - 6) North Branch Lamoille River

Route Number TH 8
Mile marker 0000

Town BELVIDERE (04375)

Road Name -

Hydrologic Unit Code: $\mathbf{0 2 0 1 0 0 0 5}$

3. Descriptive comments:

This site is located about 0.05 mile from the intersection of TH08 with VT 109. The left abutment is cemented over. The right abutment is stone.

\section{B. Bridge Deck Observations}
4. Surface cover... LBUS 4
RBUS 6
LBDS 4
RBDS 6
Overall 4

(2b us, ds,lb,rb: 1- Urban; 2- Suburban; 3- Row crops; 4- Pasture; 5- Shrub- and brushland; 6- Forest; 7- Wetland)
5. Ambient water surface... US $\underline{\mathbf{2}}$
UB 2
DS $\underline{2}$
(1- pool; 2- riffle)

6. Bridge structure type 1 (1- single span; 2- multiple span; 3- single arch; 4- multiple arch; 5-cylindrical culvert; 6- box culvert; or 7- other)
7. Bridge length $\mathbf{4 0}$
(feet)
Span length $\underline{\mathbf{3 7}}$
(feet)
Bridge width 12.6 (feet)

\section{Road approach to bridge:}
8. LB 1
RB 2
( 0 even, 1- lower, 2- higher)
9. LB
RB $\underline{2}$
(1- Paved, 2- Not paved)

10. Embankment slope (run / rise in feet / foot)

US left

US right

\begin{tabular}{|c|c|c|c|}
\hline \multicolumn{2}{|c|}{ Protection } & \multirow{2}{*}{ 13.Erosion } & 14.Severity \\
\hline 11.Type & 12.Cond. & $\mathbf{0}$ & - \\
\hline $\mathbf{2}$ & $\mathbf{1}$ & $\mathbf{0}$ & - \\
$\mathbf{3}$ & $\mathbf{1}$ & $\mathbf{0}$ & - \\
\hline $\mathbf{0}$ & - & $\underline{\mathbf{2}}$ & $\mathbf{1}$ \\
\hline $\mathbf{0}$ & - & $\mathbf{2}$ & $\mathbf{1}$ \\
\hline
\end{tabular}

Bank protection types: 0- none; 1- < 12 inches;

2- $<36$ inches; $3-<48$ inches;

4- < 60 inches; 5- wall / artificial levee

Bank protection conditions: 1- good; 2- slumped;

3- eroded; 4- failed

Erosion: 0 - none; 1- channel erosion; 2

road wash; 3- both; 4- other

Erosion Severity: 0 - none; 1- slight; 2- moderate; 3- severe

\section{Channel approach to bridge (BF):}

15. Angle of approach: $\mathbf{3 5}$

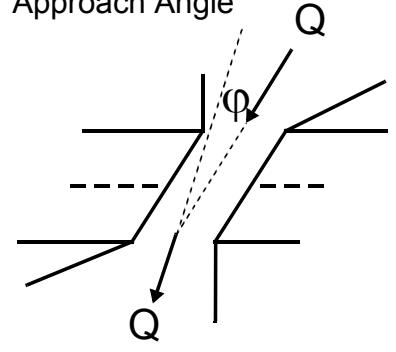

17. Channel impact zone 1:

Where? LB (LB, RB)

Range? 14 feet US

Channel impact zone 2:

Where? LB $(L B, R B)$

Range? 100 feet $\underline{\mathrm{DS}}$ (US, UB, DS) to $\underline{145}$ feet $\underline{\mathrm{DS}}$

Impact Severity: 0- none to very slight; 1- Slight; 2- Moderate; 3- Severe
16. Bridge skew: $\mathbf{3 5}$ Bridge Skew Angle

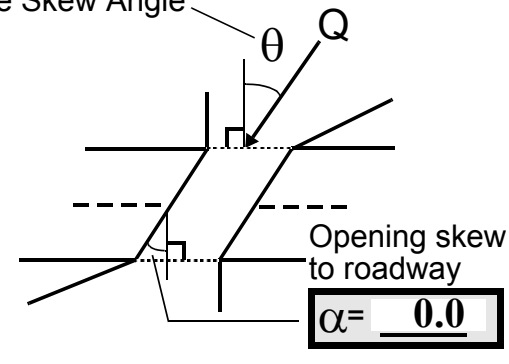

\section{Exist? $\mathbf{Y}(Y$ or $N)$}

Severity 1

US, UB, DS) to $\underline{\mathbf{0} \quad \text { feet } \underline{\mathbf{D S}}}$

Exist? $\underline{\mathbf{Y}}(\mathrm{Y}$ or $N)$

Severity $\underline{3}$ 
18. Bridge Type: $\underline{\mathbf{1 b} / \mathbf{1 a}}$

1a- Vertical abutments with wingwalls

1 b- Vertical abutments without wingwalls

2- Vertical abutments and wingwalls, sloping embankment Wingwalls perpendicular to abut. face

3- Spill through abutments

4- Sloping embankment, vertical wingwalls and abutments

Wingwall angle less than $90^{\circ}$.

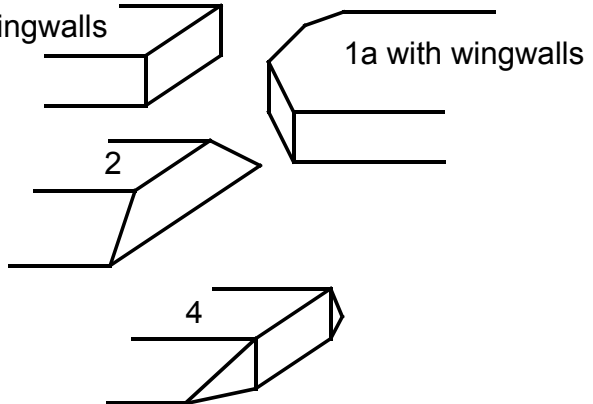

19. Bridge Deck Comments (surface cover variations, measured bridge and span lengths, bridge type variations, approach overflow width, etc.)

The right abutment has no wingwalls and is made of stone with a concrete bridge seat. The left abutment has a concrete cap and angled wingwalls.

Each of the US left bank, US right bank, and DS left bank has a house, a gravel driveway, and a lawn yard. The house on the US right bank sits very high on the bank. The immediate banks have trees and shrubs. There is an additional moderate channel impact on the right road approach embankment from 0 to 30 feet upstream.

\section{Upstream Channel Assessment}

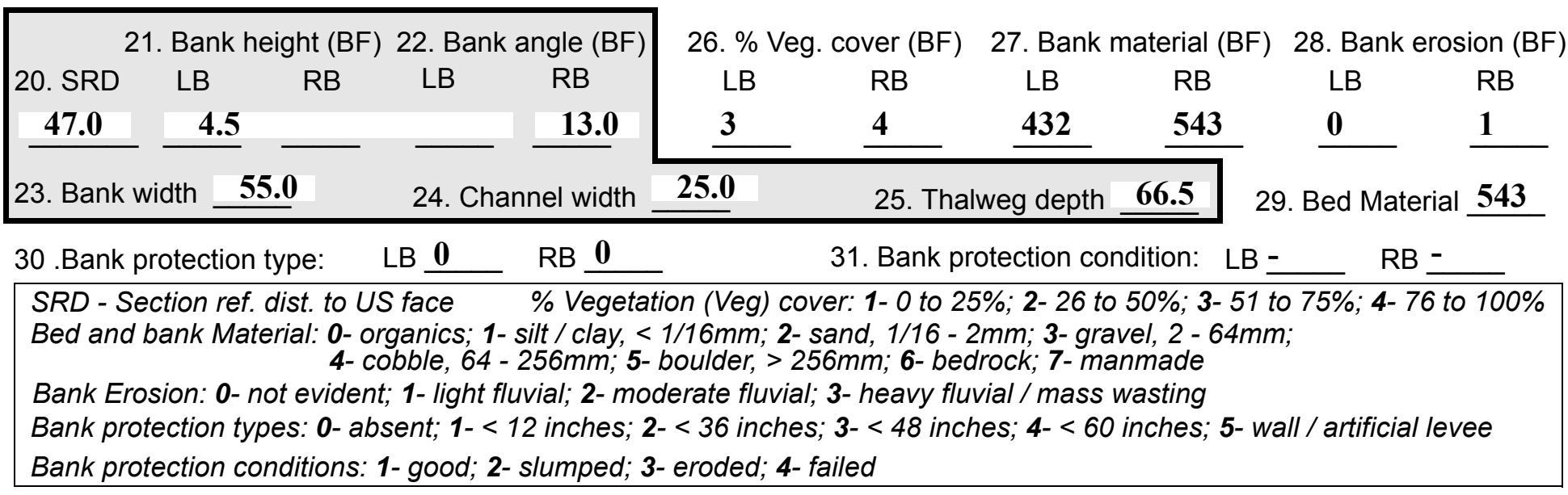

32. Comments (bank material variation, minor inflows, protection extent, etc.):

There is a minor inflow flowing along the US left road approach and down along the wingwall. 
33.Point/Side bar present? $\mathbf{Y}$

$(Y$ or N. if $N$ type ctrl-n pb)34. Mid-bar distance: $\mathbf{1 0 0}$

35. Mid-bar width: 20

36. Point bar extent: $\underline{40}$ feet $\underline{\text { US }}$ (US, UB) to 215 feet $\underline{\mathbf{U S}}$ (US, UB, DS) positioned $\underline{\mathbf{6 0}} \%$ LB to $100 \%$ RB

37. Material: $4 \mathbf{4 5 3}$

38. Point or side bar comments (Circle Point or Side; Note additional bars, material variation, status, etc.):

Point bar grades to smaller particles going DS.

39. Is a cut-bank present? $\mathbf{Y}$ ( $Y$ or if $N$ type ctrl-n $c b)$

40. Where? $\mathbf{R B} \quad(L B$ or $R B)$

41. Mid-bank distance: 132

42. Cut bank extent: $\mathbf{8 5}$

(US, UB) to $\underline{\mathbf{1 8 0}}$ feet $\underline{\mathrm{US}}$ (US, UB, DS)

43. Bank damage: 1

(1- eroded and/or creep; 2- slip failure; 3- block failure)

44. Cut bank comments (eg. additional cut banks, protection condition, etc.):

\section{Is channel scour present? $\mathbf{N}$ ( $Y$ or if $N$ type ctrl-n cs)}

47. Scour dimensions: Length -

Width -

Depth :-

46. Mid-scour distance: -

48. Scour comments (eg. additional scour areas, local scouring process, etc.):

NO CHANNEL SCOUR

49. Are there major confluences? $\mathbf{N}$

51. Confluence 1: Distance -

Confluence 2: Distance -

NO MAJOR CONFLUENCES
( $Y$ or if $N$ type ctrl-n $m c$ )

52. Enters on -

Enters on ( $L B$ or $R B)$ ( $L B$ or $R B)$
50. How many? -

53. Type(1- perennial; 2- ephemeral)

Type (1- perennial; 2- ephemeral)

\section{Under Bridge Channel Assessment}

55. Channel restraint (BF)? LB 2

56. Height (BF)
LB RB
34.5
58. Bank width (BF) -

59. Channel width (Amb)

(1- natural bank; 2- abutment; 3- artificial levee)

Bed and bank Material: 0- organics; 1- silt / clay, < 1/16mm; 2- sand, 1/16 - 2mm; 3- gravel, 2 - 64mm; 4- cobble, 64 - 256mm; 5- boulder, > 256mm; 6- bedrock; 7- manmade

Bank Erosion: 0- not evident; 1- light fluvial; 2- moderate fluvial; 3- heavy fluvial / mass wasting

64. Comments (bank material variation, minor inflows, protection extent, etc.):

5

There is some free-poured concrete covering and protecting the streambed at the bottom of the right abutment wall, particularly at the upstream end. 
65. Debris and Ice Is there debris accumulation?

(Yor $N)$ 66. Where? $\mathbf{N}$

(1- Upstream; 2- At bridge; 3- Both)

67. Debris Potential ( 1- Low; 2- Moderate; 3- High)

68. Capture Efficiency 1 (1-Low; 2- Moderate; 3- High)

69. Is there evidence of ice build-up? 2 (Y or $N)$

Ice Blockage Potential $\mathbf{N}$

(1- Low; 2- Moderate; 3- High)

70. Debris and Ice Comments:

2

The bridge and boulders constrict the channel as much as $50 \%$ in width but the high gradient, straight alignment and the high bridge deck should reduce ice blockage.

\begin{tabular}{|l|c|c|c|c|c|c|c|c|}
\hline Abutments & $\begin{array}{c}\text { 71. Attack } \\
\angle \text { (BF) }\end{array}$ & $\begin{array}{c}\text { 72. Slope } \angle \\
\text { (Qmax) }\end{array}$ & $\begin{array}{c}\text { 73. Toe } \\
\text { loc. (BF) }\end{array}$ & $\begin{array}{c}\text { 74. Scour } \\
\text { Condition }\end{array}$ & $\begin{array}{c}75 . \text { Scour } \\
\text { depth }\end{array}$ & $\begin{array}{c}\text { 76. Exposure } \\
\text { depth }\end{array}$ & 77. Material & 78. Length \\
\hline LABUT & & $\mathbf{3 0}$ & $\mathbf{9 0}$ & $\mathbf{2}$ & $\mathbf{0}$ & - & - & $\mathbf{9 0 . 0}$ \\
\hline RABUT & $\mathbf{2}$ & - & $\mathbf{9 0}$ & & & $\mathbf{2}$ & $\mathbf{0}$ & $\mathbf{3 2 . 5}$ \\
\hline
\end{tabular}

Pushed: $L B$ or RB

Toe Location (Loc.): 0- even, 1- set back, 2- protrudes

Scour cond.: 0- not evident; 1- evident (comment); 2- footing exposed; 3-undermined footing; 4- piling exposed; 5- settled; 6- failed

Materials: 1- Concrete; 2- Stone masonry or drywall; 3- steel or metal; 4- wood

79. Abutment comments (eg. undermined penetration, unusual scour processes, debris, etc.):

-

2

The abutments are not parallel. They are each angled inward towards the DS end relative to the bridge deck a few degrees creating a greater DS constriction.

80. Wingwalls: $\begin{array}{llll} & & & \\ \text { Exist? Material? } & \text { Scour } & \text { Scour } & \text { Exposure } \\ \text { Condition? } & \text { depth? } & \text { depth? }\end{array}$

USLWW:

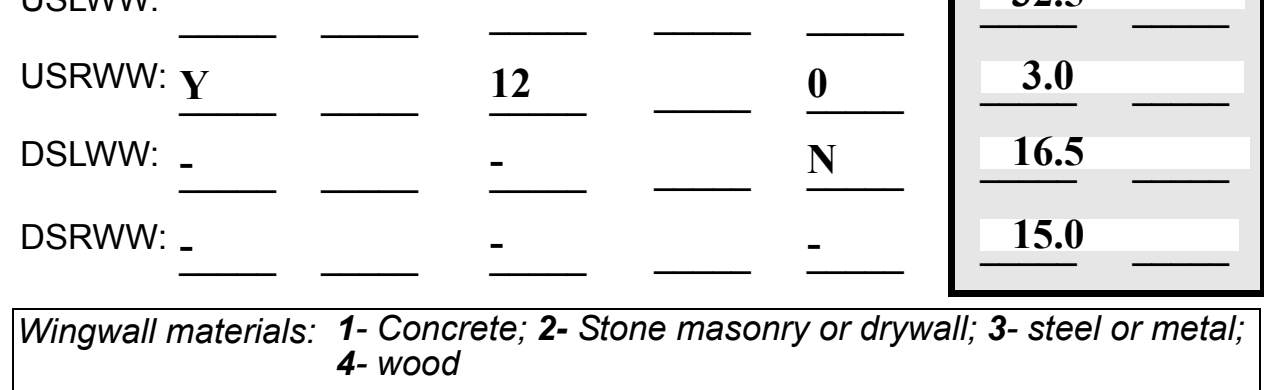

32.5

4- wood

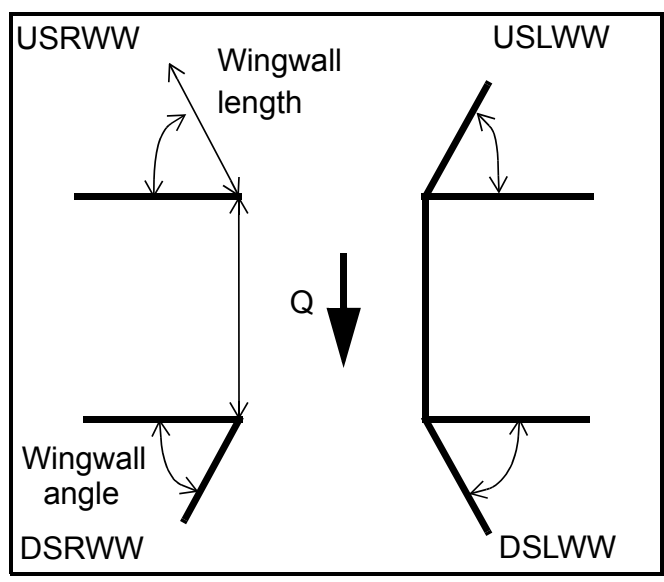

82. Bank / Bridge Protection:

\begin{tabular}{|l|l|l|l|l|l|l|l|l|}
\hline Location & USLWW & USRWW & LABUT & RABUT & LB & RB & DSLWW & DSRWW \\
\hline Type & - & $\mathbf{0}$ & $\mathbf{N}$ & - & $\mathbf{1}$ & - & $\mathbf{1}$ & $\mathbf{2}$ \\
\hline Condition & $\mathbf{Y}$ & - & - & - & $\mathbf{1}$ & - & $\mathbf{1}$ & $\mathbf{1}$ \\
\hline Extent & $\mathbf{1}$ & - & - & $\mathbf{3}$ & - & $\mathbf{3}$ & $\mathbf{2}$ & - \\
\hline
\end{tabular}

Bank / Bridge protection types: 0- absent; 1- < 12 inches; 2- < 36 inches; 3- < 48 inches; 4- < 60 inches; 
83. Wingwall and protection comments (eg. undermined penetration, unusual scour processes, etc.):

-
-
-
-
-
3
1
1
-
-
-

\section{Piers:}

84. Are there piers? Th (Y or if N type ctrl-n pr)

\begin{tabular}{|l|l|l|l|l|l|l|l|}
\hline \multirow{2}{*}{$\begin{array}{l}85 . \\
\text { Pier no. }\end{array}$} & \multicolumn{3}{|c|}{ width (w) feet } & \multicolumn{3}{c|}{ elevation (e) feet } \\
\cline { 2 - 9 } & w1 & w2 & w3 & e@w1 & e@w2 & e@w3 \\
\hline Pier 1 & & $\mathbf{5 . 0}$ & - & $\mathbf{6 0 . 0}$ & - & $\mathbf{3 0 . 0}$ \\
\hline Pier 2 & & - & - & $\mathbf{1 2 . 0}$ & - & - \\
\hline Pier 3 & - & - & - & - & - & - \\
\hline Pier 4 & - & - & - & - & - & - \\
\hline
\end{tabular}

\begin{tabular}{|l|l|l|l|l|}
\hline Level 1 Pier Descr. & \multicolumn{1}{|c|}{1} & \multicolumn{1}{|c|}{2} & \multicolumn{1}{|c|}{4} & \multicolumn{1}{|c|}{} \\
\hline 86. Location (BF) & e abut- & there- & as & \\
\hline 87. Type & ment & fore & oppo & \\
\hline 88. Material & walls & the & sed & \\
\hline 89. Shape & are & pro- & to & N \\
\hline 90. Inclined? & mold & tec- & stone & - \\
\hline 91. Attack $\angle$ (BF) & ed & tion & fill. & - \\
\hline 92. Pushed & into & may & & - \\
\hline 93. Length (feet) & - & - & - & - \\
\hline 94. \# of piles & the & be & & - \\
\hline 95. Cross-members & pro- & nativ & & - \\
\hline 96. Scour Condition & tec- & e & & - \\
\hline 97. Scour depth & tion & boul- & & - \\
\hline 98. Exposure depth & and & ders & & - \\
\hline
\end{tabular}

LFP, LTB, LB, MCL, MCM, MCR, RB, RTB, RFP

1- Solid pier, 2- column, 3- bent

1-Wood; 2- concrete; 3- metal; 4- stone

1- Round; 2- Square; 3- Pointed

Y-yes; $N$ - no

$L B$ or $R B$

0- none; 1- laterals; 2- diagonals; 3- both

0- not evident; 1- evident (comment);

2- footing exposed; 3- piling exposed;

4- undermined footing; 5- settled; 6- failed 
99. Pier comments (eg. undermined penetration, protection and protection extent, unusual scour processes, etc.):

-
-
-
-
-
-
-
-
-

100.

\section{E. Downstream Channel Assessment}

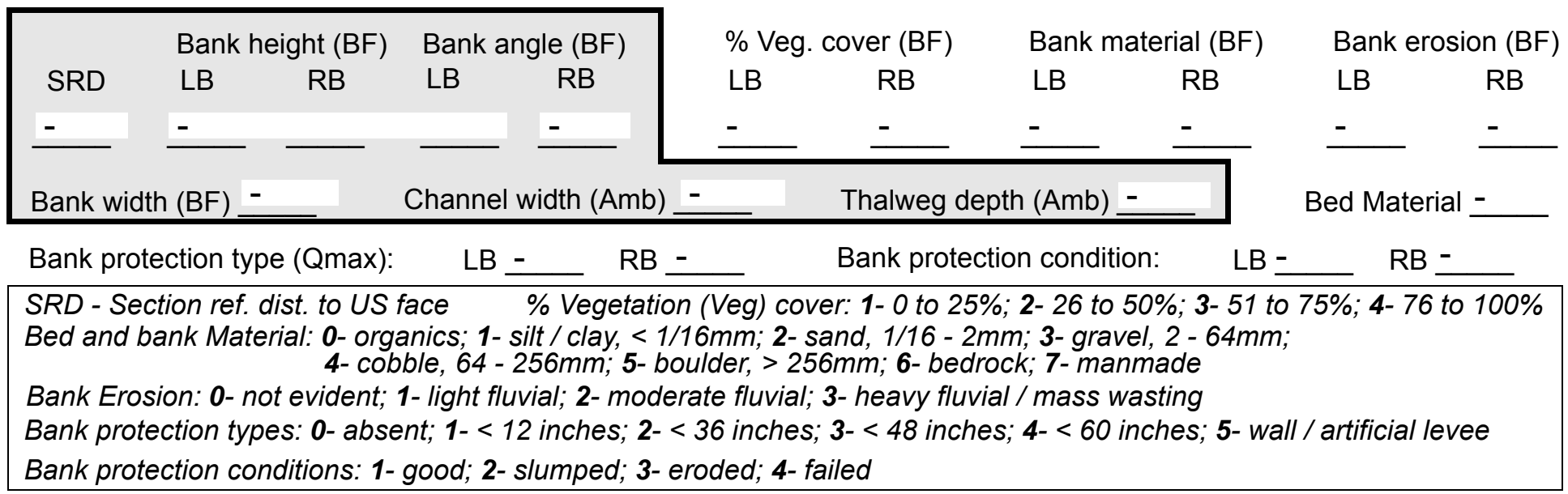

Comments (eg. bank material variation, minor inflows, protection extent, etc.):

$-$

$-$

$-$

$-$

-

$-$

$-$

-

-

-

-

-

-

-

-

101. Is a drop structure present? _ ( $Y$ or $N$, if $N$ type ctrl-n ds) 102. Distance: __ feet
103. Drop: - feet
104. Structure material: -
(1- steel sheet pile; 2- wood pile; 3-concrete; 4- other)

105. Drop structure comments (eg. downstream scour depth):

-

-

\section{NO PIERS}


106. Point/Side bar present? (Y or $N$. if $N$ type ctrl-n pb)Mid-bar distance:

Mid-bar width:

Point bar extent: feet

(US, UB, DS) to feet 3 (US, UB, DS) positioned 4 \%LB to $\underline{543} \%$ RB

Material: $\mathbf{4 3 2}$

Point or side bar comments (Circle Point or Side; note additional bars, material variation, status, etc.):

$-$

543

$-$

Is a cut-bank present? _ _ (Y or if N type ctrl-n cb) Where? -_ (LB or RB) Mid-bank distance: -

Cut bank extent: Ther feet $\underline{\mathbf{e} \text { is }}$ (US, UB, DS) to bed- feet roc (US, UB, DS)

Bank damage: $\mathbf{k}$ (1-eroded and/or creep; 2- slip failure; 3- block failure)

Cut bank comments (eg. additional cut banks, protection condition, etc.):

on the left bank from 100-145 feet DS. There are tree roots exposed on both banks.

Is channel scour present? ( $Y$ or if $N$ type ctrl-n cs)

Mid-scour distance:

Scour dimensions: Length Width Depth:

Positioned $\%$ LB to $\% \mathrm{RB}$

Scour comments (eg. additional scour areas, local scouring process, etc.):

Are there major confluences? $\mathbf{N}$ ( $Y$ or if $N$ type ctrl-n $m c)$

Confluence 1: Distance NO

Confluence 2: Distance $\underline{\text { STR }}$ Enters on $\underline{\mathbf{D R}}$ (LB or $R B)$

Enters on $\underline{\mathbf{U C}}(L B$ or $R B)$

Confluence comments (eg. confluence name):

RE

\section{F. Geomorphic Channel Assessment}

107. Stage of reach evolution
1- Constructed

2- Stable

3- Aggraded

4- Degraded

5- Laterally unstable

6- Vertically and laterally unstable 
108. Evolution comments (Channel evolution not considering bridge effects; See HEC-20, Figure 1 for geomorphic descriptors):

Y
165
27
85
DS
230
DS
40
100
543




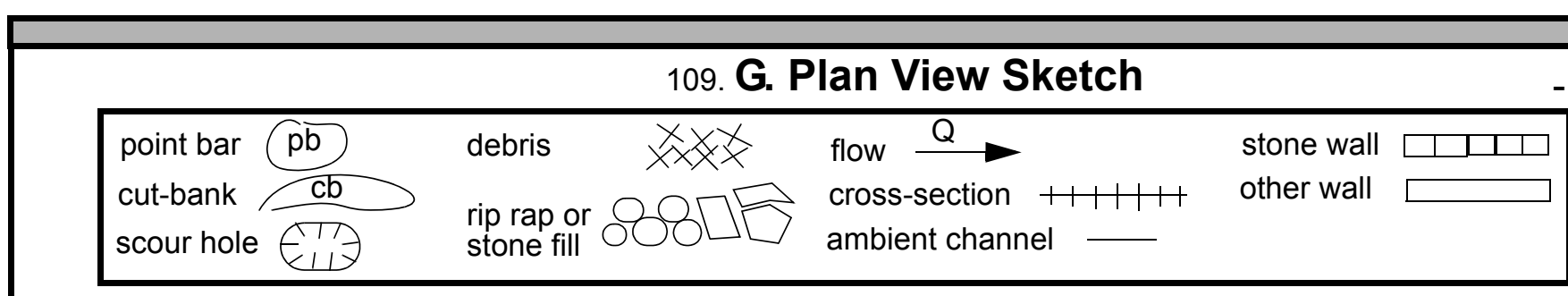

cut-bank $\mathrm{cb}$

scour hole rip rap or
stone fill stone fill cross-section $+1+1+1$ ambient channe other wall 
APPENDIX F:

SCOUR COMPUTATIONS 


\begin{tabular}{|c|c|c|c|}
\hline $\begin{array}{ll}\text { Structure Number: } & \text { BELVTH00080011 } \\
\text { Road Number: } & \text { TH } 8 \\
\text { Stream: } & \text { North Branch Lamoi }\end{array}$ & ille River & $\begin{array}{l}\text { Town: } \\
\text { County: }\end{array}$ & $\begin{array}{l}\text { Belvidere } \\
\text { Lamoille }\end{array}$ \\
\hline Initials EMB & Checked: & SAO & $6 / 12 / 97$ \\
\hline nalysis of contraction scour, live & -bed or $\mathrm{cl}$ & lear wa & \\
\hline $\begin{array}{l}\text { Critical Velocity of Bed Material } \\
\text { VC=11.21*y } 1^{\wedge} 0.1667 * \mathrm{D} 50^{\wedge} 0.33 \text { with Ss= } \\
\text { (Richardson and others, } 1995, \text { p. } 28\end{array}$ & $\begin{array}{l}\text { converted } \\
=2.65 \\
\text { eq. } 16)\end{array}$ & to Eng & sh units) \\
\hline pproach section & & & \\
\hline Characteristic & $100 \mathrm{yr}$ & $500 \mathrm{yr}$ & other $Q$ \\
\hline Total discharge, cfs & 3650 & 5400 & 3670 \\
\hline Main Channel Area, ft2 & 650 & 903 & 653 \\
\hline Left overbank area, ft2 & 131 & 524 & 135 \\
\hline Right overbank area, ft2 & 0 & 0 & 0 \\
\hline Top width main channel, ft & 75 & 77 & 75 \\
\hline Top width L overbank, ft & 116 & 122 & 116 \\
\hline Top width $\mathrm{R}$ overbank, ft & 0 & 0 & 0 \\
\hline D50 of channel, ft & 0.5659 & 0.5659 & 0.5659 \\
\hline D50 left overbank, ft & - - & - - & - - \\
\hline D50 right overbank, ft & -- & -- & -- \\
\hline Y1, average depth, MC, ft & 8.7 & 11.7 & 8.7 \\
\hline Y1, average depth, LOB, ft & 1.1 & 4.3 & 1.2 \\
\hline Y1, average depth, ROB, ft & $\mathrm{ERR}$ & ERR & $\mathrm{ERR}$ \\
\hline Total conveyance, approach & 75924 & 169205 & 76739 \\
\hline Conveyance, main channel & 70650 & 117944 & 71153 \\
\hline Conveyance, LOB & 5274 & 51261 & 5586 \\
\hline Conveyance, ROB & 0 & 0 & 0 \\
\hline Percent discrepancy, conveyance & 0.0000 & 0.0000 & 0.0000 \\
\hline Qm, discharge, $\mathrm{MC}$, Cfs & 3396.5 & 3764.1 & 3402.9 \\
\hline Q1, discharge, LOB, Cfs & 253.5 & 1635.9 & 267.1 \\
\hline Qr, discharge, ROB, Cfs & 0.0 & 0.0 & 0.0 \\
\hline Vm, mean velocity $\mathrm{MC}, \mathrm{ft} / \mathrm{s}$ & 5.2 & 4.2 & 5.2 \\
\hline Vl, mean velocity, LOB, ft/s & 1.9 & 3.1 & 2.0 \\
\hline Vr, mean velocity, $R O B, f t / s$ & ERR & ERR & ERR \\
\hline Vc-m, crit. velocity, $\mathrm{MC}, \mathrm{ft} / \mathrm{s}$ & 13.3 & 14.0 & 13.3 \\
\hline VC-l, crit. velocity, LOB, ft/s & ERR & ERR & ERR \\
\hline VC-r, crit. velocity, ROB, ft/s & ERR & $\mathrm{ERR}$ & ERR \\
\hline Results & & & \\
\hline Live-bed(1) or Clear-Water(0) Contra & action $\mathrm{Scc}$ & our? & \\
\hline Main Channel & 0 & 0 & 0 \\
\hline V. Armoring & & & \\
\hline $\begin{array}{l}\mathrm{DC}=\left[\left(1.94 * \mathrm{~V}^{\wedge} 2\right) /(5.75 * \log (12.27 * \mathrm{y} / \mathrm{D} 9 \mathrm{C}\right. \\
\text { Depth to Armoring }=3 *(1 / \mathrm{PC}-1)\end{array}$ & $\left.0))^{\wedge} 2\right] /[0$. & $.03 *(165$ & 4) ] \\
\hline (Federal Highway Administration, 199 & 93) & & \\
\hline Downstream bridge face property & $100-\mathrm{yr}$ & $500-y r$ & Other $Q$ \\
\hline Q, discharge thru bridge $\mathrm{MC}$, cfs & 3650 & 5400 & 3670 \\
\hline Main channel area (DS), ft2 & 234 & 278 & 235 \\
\hline Main channel width (normal), ft & 30.9 & 32.7 & 30.9 \\
\hline Cum. width of piers, ft & 0.0 & 0.0 & 0.0 \\
\hline Adj. main channel width, ft & 30.9 & 32.7 & 30.9 \\
\hline D90, ft & 1.4950 & 1.4950 & 1.4950 \\
\hline D95, ft & 2.1940 & 2.1940 & 2.1940 \\
\hline Dc, critical grain size, ft & 1.4420 & 2.1160 & 1.4425 \\
\hline PC, Decimal percent coarser than DC & 0.109 & 0.053 & 0.109 \\
\hline Depth & 6 & 113.88 & 35.37 \\
\hline
\end{tabular}


Clear water Contraction Scour in MAIN CHANNEL

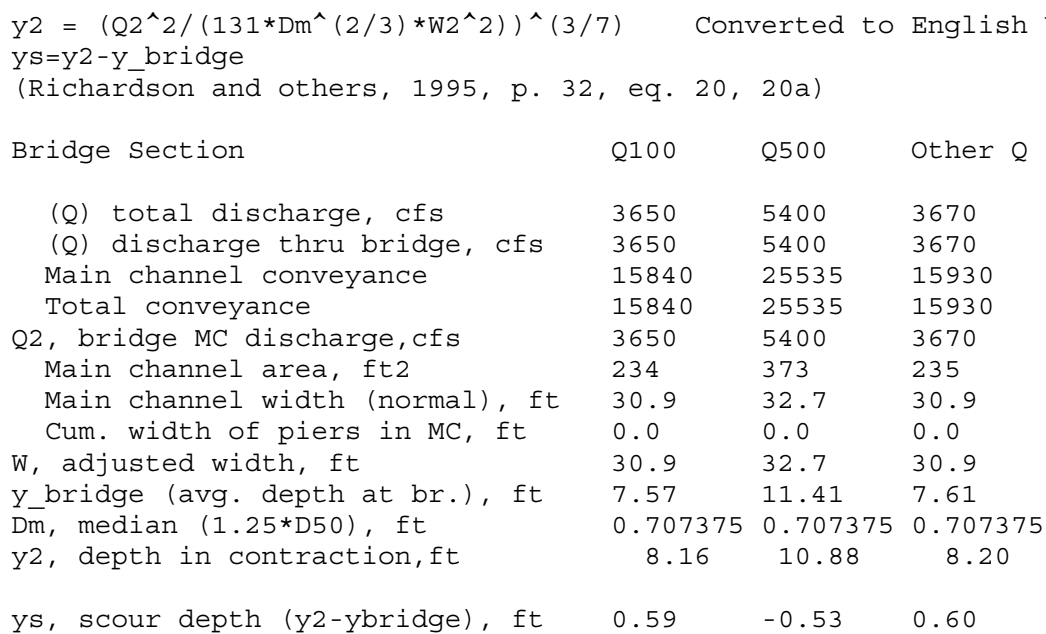

Pressure Flow Scour (contraction scour for orifice flow conditions)

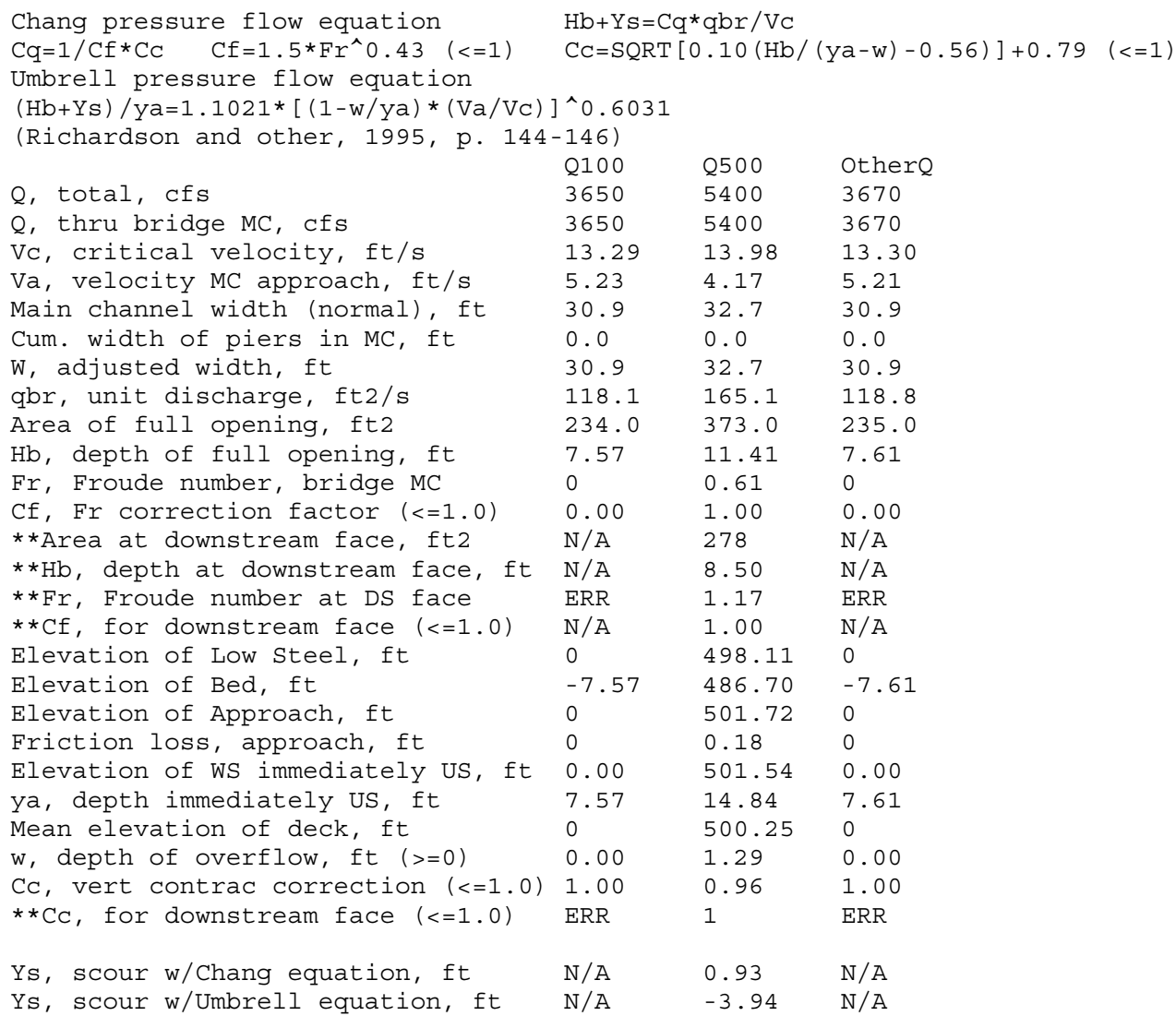

**=for UNsubmerged orifice flow using estimated downstream bridge face properties.

**Ys, scour w/Chang equation, ft N/A $3.31 \quad \mathrm{~N} / \mathrm{A}$

**Ys, scour w/Umbrell equation, ft ERR $\quad-1.04 \quad$ ERR

In UNsubmerged orifice flow, an adjusted scour depth using the Laursen equation results and the estimated downstream bridge face properties can also be computed (ys=y2-ybridgeDs)

$\begin{array}{llll}\text { Y2, from Laursen's equation, ft } & 8.16 & 10.88 & 8.20 \\ \text { WSEL at downstream face, ft } & -- & 495.11 & -- \\ \text { Depth at downstream face, ft } & \text { N/A } & 8.50 & \text { N/A } \\ \text { depth of scour (Laursen), ft } & \text { N/A } & 2.38 & \text { N/A }\end{array}$

Ys, depth of scour (Laursen), ft N/A $2.38 \quad \mathrm{~N} / \mathrm{A}$ 


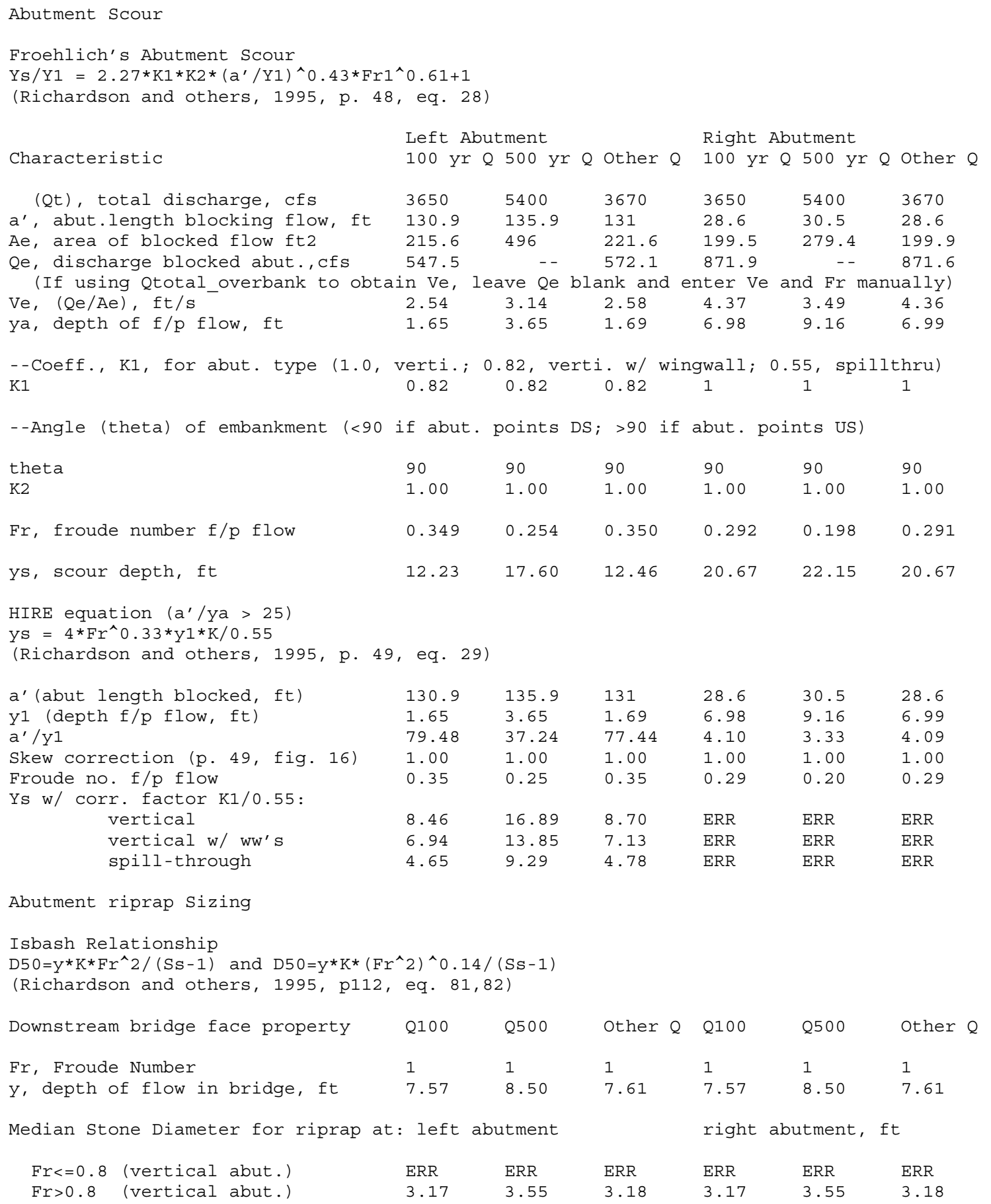

